\title{
Article \\ One-Stage Catalytic Oxidation of Adamantane to Tri-, Tetra-, and Penta-Ols
}

\author{
Igor Yu. Shchapin 1,2,3,*, Dzhamalutdin N. Ramazanov ${ }^{4}$, Andrey I. Nekhaev ${ }^{4}$, Roman S. Borisov ${ }^{4}$, \\ Evgeny A. Buravlev ${ }^{5}$ and Anton L. Maximov ${ }^{4}$
}

Citation: Shchapin, I.Yu.;

Ramazanov, D.N.; Nekhaev, A.I.;

Borisov, R.S.; Buravlev, E.A.;

Maximov, A.L. One-Stage Catalytic Oxidation of Adamantane to Tri-,

Tetra-, and Penta-Ols. Catalysts 2021,

11, 1017. https://doi.org/10.3390/

catal11081017

Academic Editor: Sónia Carabineiro

Received: 3 August 2021

Accepted: 20 August 2021

Published: 23 August 2021

Publisher's Note: MDPI stays neutra with regard to jurisdictional claims in published maps and institutional affiliations.

Copyright: (c) 2021 by the authors. Licensee MDPI, Basel, Switzerland. This article is an open access article distributed under the terms and conditions of the Creative Commons Attribution (CC BY) license (https:// creativecommons.org/licenses/by/ $4.0 /)$.
1 Department of Chemistry, I.M. Sechenov First Moscow State Medical University, 119991 Moscow, Russia

2 Department of High Energy Chemistry and Radioecology, D.I. Mendeleev University of Chemical Technology of Russia, 125047 Moscow, Russia

3 Branch of Joint-Stock Company "United Rocket and Space Corporation" - "Scientific Research Institute of Space Device Engineering", 111024 Moscow, Russia

4 A.V. Topchiev Institute of Petrochemical Synthesis, Russian Academy of Sciences, 119991 Moscow, Russia; ramazanov@ips.ac.ru (D.N.R.); nekhaev@ips.ac.ru (A.I.N.); borisov@ips.ac.ru (R.S.B.); max@ips.ac.ru (A.L.M.)

5 Department of Physics and Mathematics, N.I. Pirogov Russian National Research Medical University, 117997 Moscow, Russia; evgenii.sci@gmail.com

* Correspondence: shchapin@yandex.ru

\begin{abstract}
Tertiary tetraols of adamantane $\left(\mathrm{C}_{10} \mathrm{H}_{16}\right.$, Tricyclo[3.3.1.1(3,7)]decan) have been widely used for the synthesis of highly symmetric compounds with unique physical and chemical properties. The methods for one-stage simultaneously selective, deep, and cheap oxidation of adamantane to tetraols of different structures have not yet been developed. In this research, chemically simple, cheap, and environmentally friendly reagents are used and that is the first step in this direction. The conditions, under which the impact of a hydrogen peroxide water solution on adamantane dissolved in acetonitrile results in full conversion of adamantane and formation of a total $72 \%$ mixture of its tri-, tetra-, and penta-oxygenated products, predominantly poliols, have been found. Conversion and adamantane oxidation depth are shown to depend on the ratio of components of the water-acetonitrile solution and the method of oxidizer solution introduction when using the dimer form of 1:1 dimethylglyoxime and copper dichloride complex as a catalyst. Under the conditions of mass-spectrometry ionization by electrons $(70 \mathrm{eV})$, fragmentation across three $\mathrm{C}-\mathrm{C}$ bonds of the molecular ions framework of adamantane tertiary alcohols $\mathrm{Ad}(\mathrm{OH})_{\mathrm{n}}$ in the range $n=0-4$ increases linearly with the rise of $n$.
\end{abstract}

Keywords: adamantane; catalytic oxidation; $\mathrm{Cu}(\mathrm{II})$, hydrogen peroxide; 1,3,5-trihydroxyadamantane; 1,3,5,7-tetrahydroxyadamantane; mass spectrometry

\section{Introduction}

Adamantane (Tricyclo[3.3.1.1(3,7)]decane, Ad, 0) (Scheme 1) can be oxidized to different compounds in different ways. In the general Scheme 1 and further in the numbering used in this paper, the numbers $\mathbf{0}, \mathbf{1}, 2,3,4$, and 5 indicate the number of oxygen atoms in the composition of the chemical compound.

Medically, there is a certain interest in the oxidation of $\mathbf{0}$ since its derivatives are used to obtain drugs, the therapeutic effect of which and the composition of metabolites are described and systematized in the studies [1-5].

Oxidation of $\mathbf{0}$ can be considered from two points of view: positional selectivity and oxidation depth. The largest number of works is devoted to the oxidation of $\mathbf{0}$ to a mixture of monooxygenated (1O-Ad) products with a predominance of one of the following: 1-adamantanol (1a) [6-12], 2-adamantanol (1b) [13], and 2-adamantanone (1c) [14] (Scheme 1). 


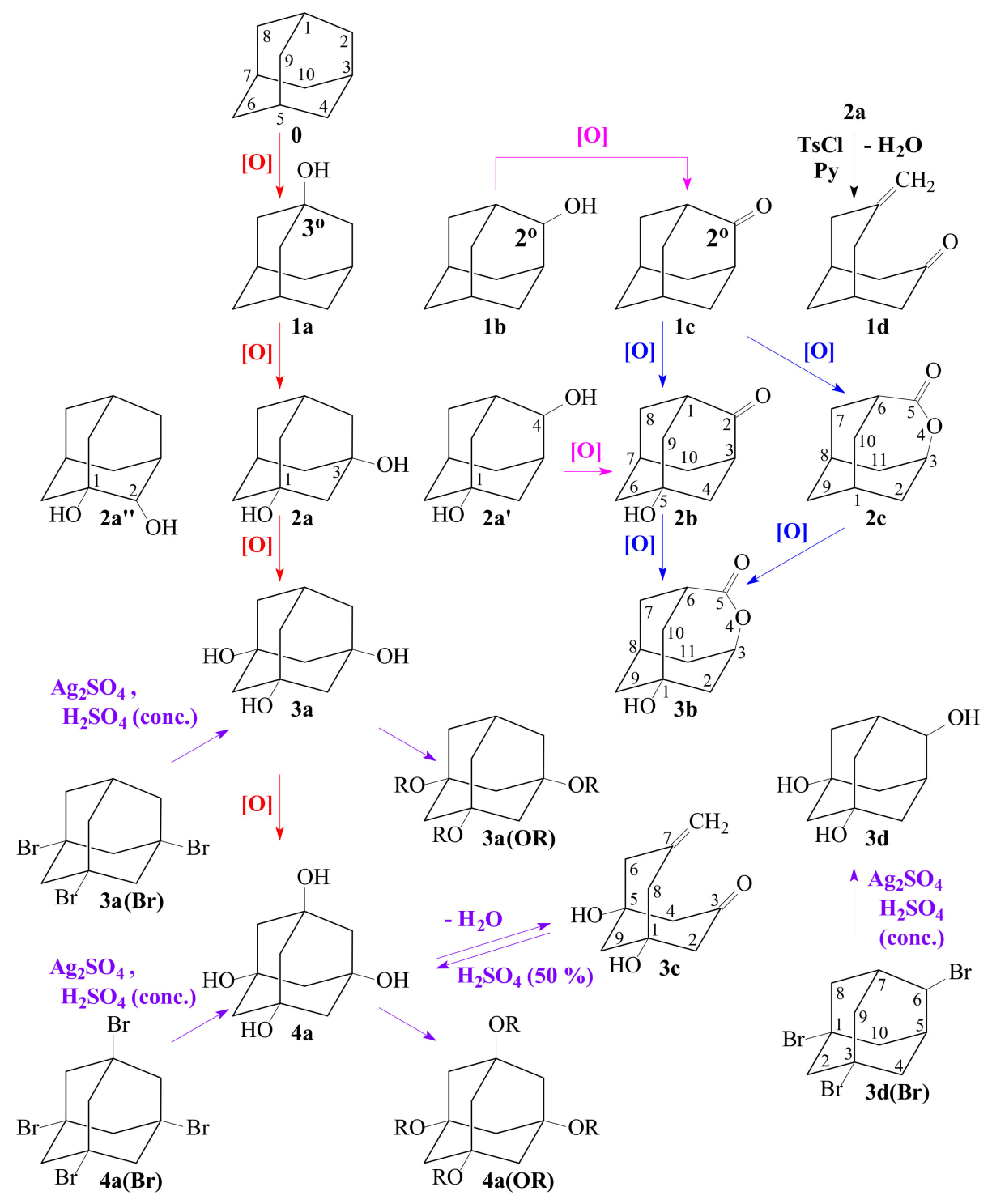

Scheme 1. Products of 0 oxidation.

In such works, the conversion of $\mathbf{0}(\mathrm{C})$ may be small. The main focus is given to the positional selectivity of oxidation of $\mathbf{0}$, the quantitative characteristic of which is the ratio of the amounts of products $\mathbf{1 a}$ and $\mathbf{1 b}+\mathbf{1 c}$ of oxidation of $\mathbf{0}$ normalized by one $\mathrm{C}-\mathrm{H}$ bond of each type, respectively, according to the tertiary $\left(3^{\circ}\right)$ and secondary $\left(2^{\circ}\right)$ positions (the ratio of $3^{\circ}: 2^{\circ}$ ) (Scheme 1). The positional selectivity of oxidation of 0 allows for drawing conclusions about the reaction mechanism $[15,16]$.

To date, there are no works in which experimental factors that affect the oxidation depth of $\mathbf{0}$-the total number of oxygen atoms included in all its oxidation products-have been systematically studied.

The oxidation depth increases with an increase in C, with an increase in the number of oxygen atoms in the products. During the sequential oxidation of $\mathbf{0}$ and its tertiary alcohols $\mathbf{0} \rightarrow \mathbf{1 a} \rightarrow \mathbf{2} \mathbf{a} \rightarrow \mathbf{3 a} \rightarrow \mathbf{4 a}$ (Scheme 1), as well as with an increase in the amounts of deeper oxidized products.

With an increase in the oxidation depth of $\mathbf{0}$, the composition of the products becomes more complicated. Therefore, $\mathbf{1} \mathbf{a}, \mathbf{1} \mathbf{b}$, and $\mathbf{1} \mathbf{c}$ are usually oxidized to dioxygenated (2O-Ad) products, based on monooxygenated products, and not on 0 [17-22]. 
Tertiary alcohol $\mathbf{1 a}$ can be oxidized to 1,2-, 1,3-, and 1,4-diols (2a', $\mathbf{2 a}$, and $\mathbf{2} \mathbf{a}^{\prime}$, respectively), of which $\mathbf{2} \mathbf{a}^{\prime}$ and $\mathbf{2} \mathbf{a}^{\prime \prime}$, containing secondary alcohol groups, are capable of further oxidation to keto-alcohols-5-hydroxy-adamantane-2-one (2b) (Scheme 1) [17] and to 1-hydroxy-adamantane-2-one (2 $\mathbf{b}^{\prime}$ ) (not shown in Scheme 1), respectively [18].

Secondary alcohol $\mathbf{1 b}$ is oxidized to ketone $\mathbf{1 c}$ [17-20], to secondary diols, and then to their corresponding keto-alcohols and diketones (not shown in Scheme 1) [17].

Ketone $\mathbf{1 c}$ is oxidized to $\mathbf{2 b}$ and to 4-oxahomoadamantane-5-one (lactone $\mathbf{2 c}$ ) (BayerWilliger reaction) [22,23].

Dehydration of $\mathbf{2 a}$ with the opening of the $\mathbf{0}$ framework leads to 7-methylene bicyclo[3.3.1]nona-3-one (1d) (Scheme 1)-isomer 1c [24,25]. The radical anion $\mathbf{1 d}^{\mathbf{\bullet}}$ is cyclized to form the noradamantane product and 1a [26].

When $\mathbf{0}$ is oxidized to tri- and tetra-oxygenated products (3O-Ad and $4 \mathrm{O}-\mathrm{Ad}$, respectively), the composition of the product becomes even more complicated.

Therefore, even when using highly selective $3^{\circ}$-position biological oxidation methods (enzymes, bacteria, microbes, cells [27-37]) to obtain 1,3,5-adamantantriol (3a), preference was given to sequential oxidation of $\mathbf{0}, \mathbf{1} \mathbf{a}$, and $\mathbf{2 a}$ with product isolation stages, so multistage synthesis was carried out [28-30].

Under the same conditions, the biooxidation of secondary alcohol $\mathbf{1 b}$ and ketone $\mathbf{1 c}$ does not occur selectively at the $2^{\circ}$ and $3^{\circ}$ positions [31,34]. Under other conditions, the biooxidation of ketone $\mathbf{1 c}$ through the intermediate formation of two products $\mathbf{2 b}$ and $\mathbf{2 c}$ leads to one product-1-hydroxy-4-oxahomoadamantan-5-one (3b) (Scheme 1), but with a low yield [36].

Among the 3O-Ad and 4O-Ad products, the tertiary alcohols 3a and 1,3,5,7-adamantantetraol (4a) are of the greatest practical importance.

Usually, $3 \mathbf{a}$ and $4 \mathbf{a}$ are synthesized as a precursor to obtaining derivatives of $\mathbf{3 a}(\mathbf{O R})$ and $4 \mathbf{a}(\mathbf{O R})$, respectively, where $\mathrm{R}$ is represented by many classes of compounds [38-53].

Compounds $4 \mathbf{a}(\mathrm{OR})$ by themselves and in copolymerization with other components are capable of producing stellate, reticular, and skeletal spatial structures that have numerous chemical and physical properties useful for technical applications [40-53].

1,3,5,7-aryladamantanes (4a(Ar)) are also synthesized from 4a [49,54,55].

The crystal structure of $\mathbf{4 a}$, which has the same spatial structure as $\mathrm{CsCl}$ crystals, was determined in [56].

For the synthesis of $\mathbf{3 a}$ and $\mathbf{4 a}$, the two-stage scheme was most used: (I) catalytic bromination of $\mathbf{0}$ to 1,3,5-tri- and 1,3,5,7-tetra-bromadamantane ( $\mathbf{3 a}(\mathbf{B r})$ and $\mathbf{4 a}(\mathbf{B r})$, respectively), (II) substitution of all $\mathrm{Br}$ atoms for alcohol groups (Scheme 1) [40-53].

It was shown that at stage (II), along with $4 \mathbf{a}$, a product of its dehydration was formed with the opening of the frame-1,5-dihydroxy-7-methylene-bicyclo[3.3.1]nona-3-one (3c) (Scheme 1), which can be separated from 4 a by dissolving in ethanol and using $50 \% \mathrm{H}_{2} \mathrm{SO}_{4}$ converted into an additional amount of the target product 4a [42].

The stage (II) using $\mathrm{Ag}_{2} \mathrm{SO}_{4} / \mathrm{H}_{2} \mathrm{SO}_{4}$ (conc.) is general and can be applied to tertiary mono-, di- and tri-bromadamantanes, for which single-stage syntheses have been developed starting from $\mathbf{0}[50]$.

Secondary bromadamantanes may also be involved in this reaction (II). As an example, the synthesis of triol $\mathbf{3 d}$ from $\mathbf{3} \mathbf{d}(\mathbf{B r})$ is shown in Scheme 1 [48].

This synthesis scheme is quite expensive, which hinders the widespread synthetic use of compounds $3 \mathbf{a}$ and $\mathbf{4 a}$.

With one-stage oxidation of $\mathbf{0}$ to $3 \mathbf{a}$ and $\mathbf{4 a}$, the best results were obtained when methyl(trifluoromethyl)dioxirane $\mathrm{O}_{2} \mathrm{C}\left(\mathrm{CF}_{3}\right) \mathrm{CH}_{3}$ as an oxidizer was used, with which the sequential oxidation of 0 to $2 \mathbf{a}, 3 \mathbf{a}$, and $4 \mathbf{a}$ with high yields 93,90 , and $78 \%$ occurred in $40 \mathrm{~min}, 2$ and $3 \mathrm{~h}$, respectively [57]. The unique properties of this catalytic system during the oxidation of various substrates are systematized in the review [58].

For one-stage oxidation of $\mathbf{0}$ to $3 \mathbf{a}$ with the use of hydrogen peroxide $\left(\mathrm{H}_{2} \mathrm{O}_{2}\right)$, the best results (32\%) were obtained by using a specially synthesized Fe(III) complex [59]. 
However, both of these one-stage schemes for the synthesis of $\mathbf{3 a}$ and $\mathbf{4 a}$ from $\mathbf{0}$ have not been widely used, possibly due to the peculiarities of the practical implementation of the oxidation process in the first case and the lack of availability of a catalyst in the second case.

In one-stage syntheses of $\mathbf{3 a}$ and $\mathbf{4 a}$, as well as in multi-stage syntheses, in fact, the scheme of sequential oxidation of $\mathbf{0}$ is realized, but without the stages of isolation of intermediate products. For example, since $\mathbf{3} \mathbf{a}$ is an intermediate product in the series $\mathbf{2 a}, \mathbf{3 a}$, 4a, its synthesis using different chemical reagents means searching for optimal conditions in which the target product has the highest yield [49,57-63]. It was in this way that work was carried out to find the conditions for the oxidation of $\mathbf{0}$ to $3 \mathbf{a}$ and $4 \mathbf{a}$.

In general, Scheme 1 shows all the types of $\mathbf{0}$ oxidation products described in the papers, the appearance of which was expected in the framework of this study.

At the same time, it should be noted that the products of tri- and tetra-oxygenation of $\mathbf{0}$ could include other compounds with a preserved and disclosed $\mathbf{0}$ frameworks, which will not be discussed further, since no evidence of their formation in the considered catalytic system was received.

By analogy with the oxidation of cyclohexane [64-66], such compounds could include mono- and di- hydroperoxide groups in their composition. For example, a scheme for the oxidation of $\mathbf{0}$ with the participation of its primary and secondary hydroperoxides is proposed [66], the formation of thermally stable 1-adamantylhydroperoxide (2d) [67] and 2,2-dihydroperoxy-adamantane $\left(\mathbf{4} \mathbf{a}^{\prime}\right)$ is described $[68,69]$.

Thus, to date, the problem of deep single-stage oxidation of $\mathbf{0}$ to $\mathbf{3} \mathbf{a}$ and $\mathbf{4} \mathbf{a}$ using a combination of an aqueous solution of $\mathrm{H}_{2} \mathrm{O}_{2}$-a non-explosive, environmentally friendly, cheap oxidizer, and an affordable cheap catalyst-has not been solved.

The first results of the authors' efforts to solve this problem are reported in this paper.

As a catalyst, the $\mathrm{Cu}_{2} \mathrm{Cl}_{4} \cdot 2 \mathrm{DMG}$ complex was used, where DMG-Butane-2,3-dione dioxime (dimethylglyoxime) (Scheme 2), in the presence of which, using an aqueous solution of $\mathrm{H}_{2} \mathrm{O}_{2}$, cyclohexane was previously oxidized to adipic acid with a high yield of $53 \%$ (the main product) at a conversion of cyclohexane of $30 \%$ [70].

The $\mathrm{Cu}_{2} \mathrm{Cl}_{4} \cdot 2 \mathrm{DMG}$ complex is a cheap, synthetically easily accessible reagent [71].

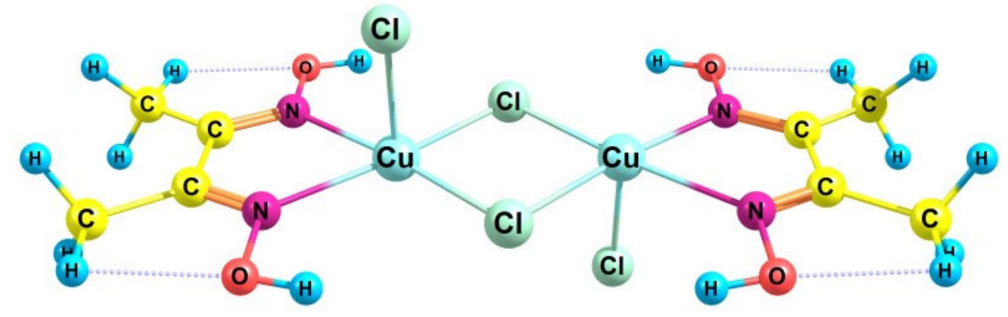

Scheme 2. The catalytic complex $\mathrm{Cu}_{2} \mathrm{Cl}_{4} \cdot 2 \mathrm{DMG}$.

The catalytic activity of the $\mathrm{Cu}_{2} \mathrm{Cl}_{4} \cdot 2 \mathrm{DMG}$ complex, although lower, is comparable to the best results obtained during the oxidation of cyclohexane and cyclohexene to adipic acid using aqueous solutions of hydrogen peroxide in the presence of metal complexes [72,73].

\section{Results}

2.1. Search for Optimal 0 Oxidation Conditions upon the Fast ( 3 s) Method of Oxidizer Solution Introduction

With the volume of the oxidizing solution $\mathrm{V}\left(\mathrm{H}_{2} \mathrm{O}_{2}\right)=1 \mathrm{~mL}$ and the mass of the catalyst $\mathrm{m}=30 \mathrm{mg}$ in the reaction temperature range $\mathrm{T}=40-70{ }^{\circ} \mathrm{C}\left(10^{\circ} \mathrm{C}\right.$-step $)$ and reaction times $t=5,30$, and $60 \mathrm{~min}$, the composition of the 0 oxidation products does not depend on $t$ and T. In the experiment, $92.5 \%$ of the total amount of identified products among $n$-oxygenation groups of $\mathbf{0}$ was divided as follows: mono- $26.4 \%$, di- $36.5 \%$, tri- $23.5 \%$, and tetra- $6.1 \%$. Unidentified products comprise $7.5 \%$. 
The dependence of the conversion $\mathrm{C}=81-89 \%$ of the 0 initial hydrocarbon on $\mathrm{T}$ is transferred by the linear equation $C=-0.281 \cdot T+100$ with the correlation coefficient $\mathrm{R}^{2}=0.9874$ (Figure $1, \mathrm{t}=30 \mathrm{~min}$ ). According to this equation, one could expect $\mathrm{C}=100 \%$ at $\mathrm{T}=0{ }^{\circ} \mathrm{C}$. However, in the experiment carried out at $\mathrm{T}=0{ }^{\circ} \mathrm{C}$ (single-wall reactor, mechanical mixing), the $\mathbf{0}$ oxidation products were not detected.

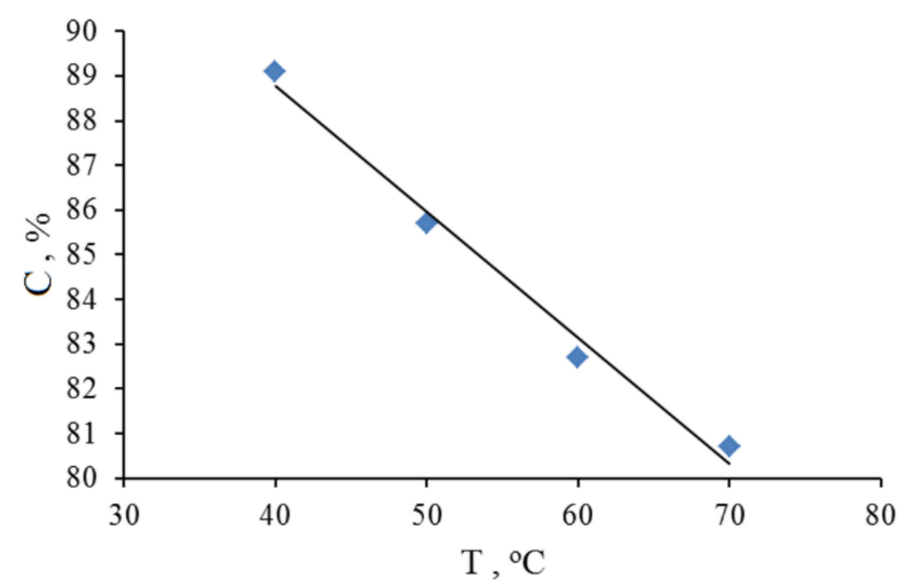

Figure 1. The dependence of the $\mathbf{0}$ conversion $(\mathrm{C})$ on the reaction temperature $\mathrm{T}$.

At $\mathrm{T}=0{ }^{\circ} \mathrm{C}$, the copper complex completely dissolved, and all $\mathbf{0}$ white flakes floated to the surface of the blue-green acetonitrile solution. At $\mathrm{T}=20^{\circ} \mathrm{C}$, the taken amount of $\mathbf{0}$ was completely soluble, but oxidation was not carried out at this temperature. The maximum value of $\mathrm{C}$, which, as it turned out, should have been at $\mathrm{T}$ less than $40{ }^{\circ} \mathrm{C}$, and not more, was not determined.

At $\mathrm{V}\left(\mathrm{H}_{2} \mathrm{O}_{2}\right)=1 \mathrm{~mL}$ and $\mathrm{T}=50{ }^{\circ} \mathrm{C}$ in the range of $\mathrm{m}=5-50 \mathrm{mg} \mathrm{Cu} \mathrm{Cl}_{4} \cdot 2 \mathrm{DMG}$, the composition of the products and conversion of $\mathbf{0}$ depended on $\mathrm{m}$ at $\mathrm{t}=5 \mathrm{~min}$ and ceased to depend on $\mathrm{t}=30$ and $60 \mathrm{~min}$. The $0 \mathrm{~K}$ conversion at $\mathrm{t}=5 \mathrm{~min}$ has a clearly pronounced inflection at $\mathrm{m}=10 \mathrm{mg}$ and a maximum of $92 \%$ at $\mathrm{m}=30 \mathrm{mg}$ (Figure 2 ).

Two groups of points: (I) $\mathrm{m}=0,5,10 \mathrm{mg}$ and (II) $\mathrm{m}=10,20,30,40,50 \mathrm{mg}$ with correlation coefficients $\mathrm{R}^{2}=1$ are located along the trend lines, respectively, $\mathrm{C}(\mathrm{I})=-0.14$ $\mathrm{m}^{2}+3.1 \mathrm{~m}$ and $\mathrm{C}(\mathrm{II})=-3 \cdot 10^{-5} \mathrm{~m}^{4}+0.0065 \mathrm{~m}^{3}-0.5525 \mathrm{~m}^{2}+18.4 \mathrm{~m}-118$.

At $\mathrm{t}=5 \mathrm{~min}$, with an increase in the catalyst mass $\mathrm{m}$ up to $30 \mathrm{mg}$, the 0 oxidation depth increased, and after reaching this value, it remained unchanged. At $t=30$ and $60 \mathrm{~min}$, $\mathrm{C}=90 \%$.

From the dependencies shown in Figure 2, two conclusions can be made. First, during the reaction time $t=5 \mathrm{~min}$, the chemical composition of the catalyst changes in the system, since there is a clearly defined inflection on the curve $C$. Second, under the above-mentioned conditions, with increasing $\mathrm{m}$, sequential oxidation occurs according to the scheme 0O-Ad $\rightarrow$ OO-Ad $\rightarrow$ 2O-Ad $\rightarrow$ 3O-Ad $\rightarrow$ 4O-Ad, and the starting compound and its oxidation products experience further parallel oxidation to an approximately equal extent.

At $\mathrm{m}=30 \mathrm{mg}$ and $\mathrm{T}=50{ }^{\circ} \mathrm{C}$, the $\mathbf{0}$ conversion and the composition of the products of its mono- $(1 \mathrm{O})$, di- $(2 \mathrm{O})$, tri- $(3 \mathrm{O})$, and tetra- $(4 \mathrm{O})$ oxygenation depend on $\mathrm{V}\left(\mathrm{H}_{2} \mathrm{O}_{2}\right)$ (Figure 3), but within the error limits (10\%) they are independent of $t$. Therefore, for each $\mathrm{V}\left(\mathrm{H}_{2} \mathrm{O}_{2}\right)$, data are averaged for $\mathrm{t}=5,30$, and $60 \mathrm{~min}$ for four groups of 0 oxidation products. 


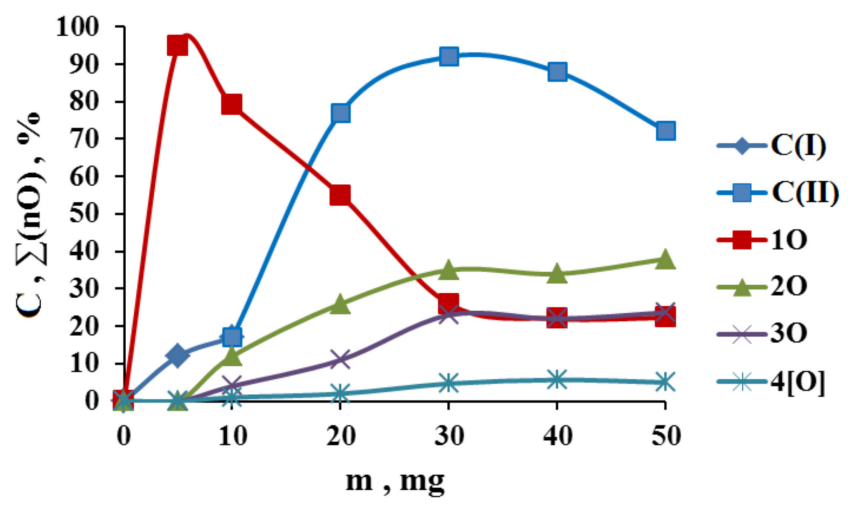

Figure 2. Dependencies of the C (C(I) $(>)$ and C(II) ( $\square)$ ) conversion and the sum of the products of 0 $n$-oxygenation, $n=1-4$, on the mass $\mathrm{m}$ of the catalyst. $\mathrm{V}\left(\mathrm{H}_{2} \mathrm{O}_{2}\right)=1 \mathrm{~mL}, \mathrm{~T}=50^{\circ} \mathrm{C}, \mathrm{t}=5 \mathrm{~min}$.

The maximum $\mathrm{C}$ falls on the interval $\mathrm{V}\left(\mathrm{H}_{2} \mathrm{O}_{2}\right)=0.5-1.0 \mathrm{~mL}$ (Figure 3). In the range $\mathrm{V}\left(\mathrm{H}_{2} \mathrm{O}_{2}\right)=0.5-2.0 \mathrm{~mL}$, the content of intermediate $2 \mathrm{O}$ products remains approximately unchanged. In the range $\mathrm{V}\left(\mathrm{H}_{2} \mathrm{O}_{2}\right)=1.5-10.0 \mathrm{~mL}$, with an increase in the volume of the oxidizing agent solution, the content of $1 \mathrm{O}$-Ad products increases linearly, and the contents of 2O-, 3O-, and 4O-Ad products decrease linearly.

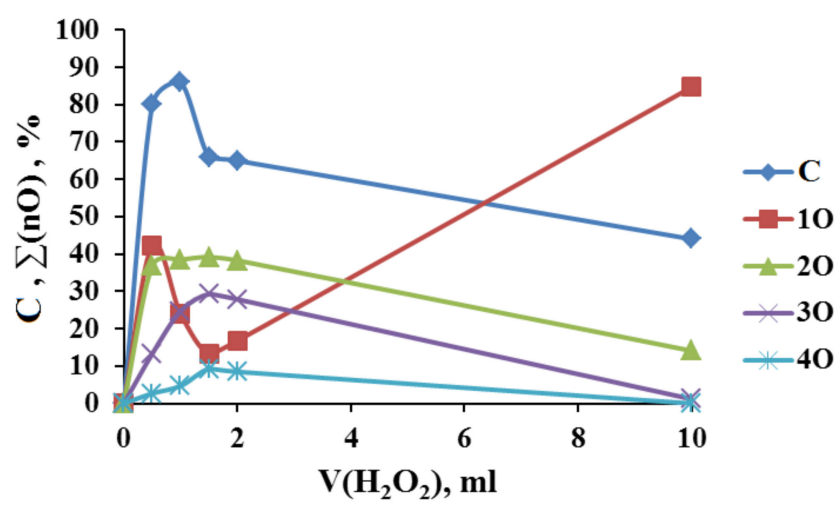

Figure 3. The 0 conversion $(\mathrm{C})$ and the sum $(\Sigma)$ of the products of its $n$-oxygenation, where $n=1-4$, in dependence on the volume $\mathrm{V}\left(\mathrm{H}_{2} \mathrm{O}_{2}\right)$ of the oxidizing solution.

In experiments on varying $\mathrm{V}\left(\mathrm{H}_{2} \mathrm{O}_{2}\right)=0.5-1.5 \mathrm{~mL}$, alcohols were predominantly formed (Scheme 3). At 0.5, 1.0, and $1.5 \mathrm{~mL}$, the ratio of products of the 1O-Ad group 1a:1b:1c was equal to 2.8:3.2:1, 4.7:4.8:1, and 1.4:1.9:1, respectively.

At $\mathrm{V}\left(\mathrm{H}_{2} \mathrm{O}_{2}\right)=1 \mathrm{~mL}$, the oxidation products of 0 were distributed in the following ratio: diols $\mathbf{2} \mathbf{a}$ and $\mathbf{2 a b}, 13.3$ and $\mathbf{1 2 . 7 \%}$, respectively, compounds $\mathbf{2 b b}, \mathbf{2 b} \mathbf{2} \mathbf{2 a c})+\mathbf{2 b c}, \mathbf{2} \mathbf{c c}, \mathbf{2} \mathbf{c}$ in the amount of $12.5 \%$, containing tertiary alcohol groups of triols $3 \mathbf{a}-11.7 \%$, other secondary triols and keto-alcohols in group 3-13\% and everything in the group of tetraols $4-4.7 \%$.

At $\mathrm{V}\left(\mathrm{H}_{2} \mathrm{O}_{2}\right)=10 \mathrm{~mL}$, the main products of oxidation of $\mathbf{0}$ were $\mathbf{1 a}(36.7 \%), \mathbf{1 b}(26.4 \%)$, and $1 \mathrm{c}(21.6 \%)$, in total $84.7 \%$ in $1 \mathrm{O}$-Ad products. The ratio of $3^{\circ}: 2^{\circ}$ was 2.3 . This value corresponds to the parallel course of several non-selective oxidation routes of $0 \mathrm{C}-\mathrm{H}$ bonds, mainly by the free radical mechanism $[15,16]$. Other products were: $\mathbf{2 a}(5.3 \%), \mathbf{2 a b}(2.4 \%)$, $\mathbf{2 b b}(5.5 \%), \mathbf{2 b}(\mathbf{2 a c})+\mathbf{2 b c}(0.4 \%)$, lactone $2 \mathbf{c}(0.5 \%)$ and $\mathbf{3}(1.2 \%)$ (Scheme 3$)$. 

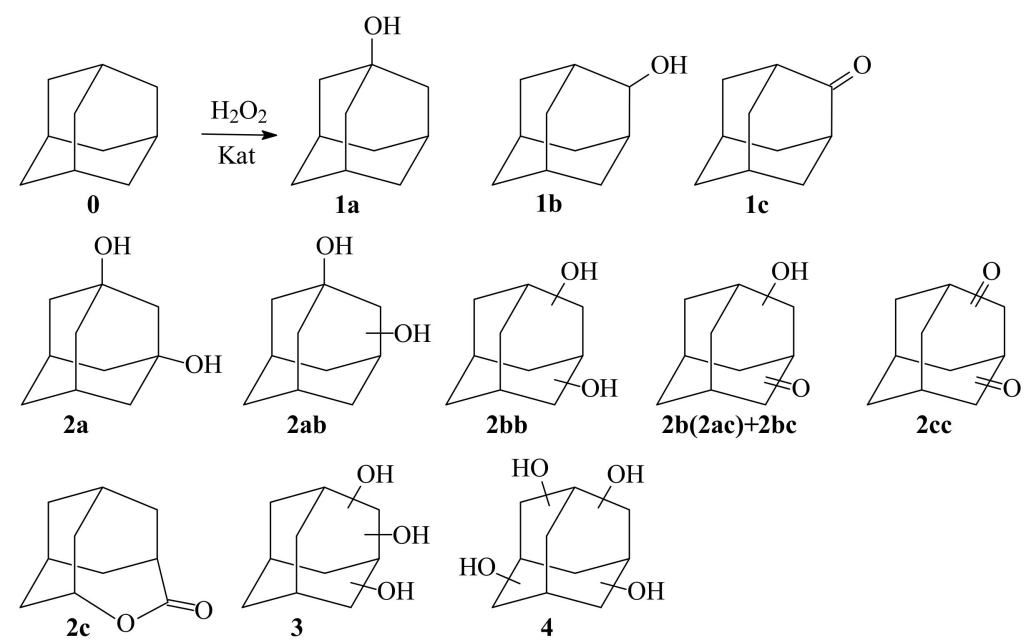

Scheme 3. Oxidation products of $\mathbf{0 .}$

2.2. Catalytic Activity of the $\mathrm{Cu}_{2} \mathrm{Cl}_{4} \cdot 2 \mathrm{DMG}$ Complex and the Release of Molecular Oxygen upon the Fast ( 3 s) Method of Oxidizer Solution Introduction

The reaction time $\mathrm{t}=5 \mathrm{~min}$ at $\mathrm{m}=30 \mathrm{mg}$ and $\mathrm{T}=50^{\circ} \mathrm{C}$, as well as for other values, was chosen based on visual observations. Around this time in the $0 / \mathrm{H}_{2} \mathrm{O}_{2} / \mathrm{Cu}_{2} \mathrm{Cl}_{4} \cdot 2 \mathrm{DMG} / \mathrm{CH}_{3} \mathrm{CN}$ system, gas began to be released, presumably it was molecular oxygen $\left(\mathrm{O}_{2}\right)$, the solution color was changing and precipitation was appearing.

The independence of $C$ and output of 0 oxidation products of the time $t=5,30$ and $60 \mathrm{~min}$ at $\mathrm{m}=30 \mathrm{mg}$ and $\mathrm{T}=50{ }^{\circ} \mathrm{C}$ (the averaged values are used in Figure 3 ) means that all the products of $\mathbf{0} n$-oxygenation are formed in the initial stage of $\mathbf{0}$ oxidation during $t=5 \mathrm{~min}$ in the presence of the original form of the $\mathrm{Cu}_{2} \mathrm{Cl}_{4} \cdot 2 \mathrm{DMG}$ catalyst. After the breakdown of this catalyst form, the formation of $\mathbf{0}$ oxidation products is terminated and the emission of gas on the other catalytic forms containing copper ions occurs.

\subsection{Adamantane (0) Oxidation upon the Slow (60 min) Method of Oxidizer Solution Introduction}

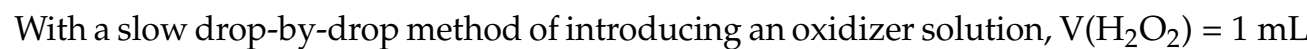
was used, at which earlier (see Figure 3), the highest $\mathbf{0}$ conversion was obtained. The search for optimal conditions (variation of $\mathrm{m}, \mathrm{t}$, and $\mathrm{V}\left(\mathrm{H}_{2} \mathrm{O}_{2}\right)$ ) at a slow $(60 \mathrm{~min})$ method of introducing the oxidizer solution was not carried out.

$\mathrm{T}$ oxidation reactions with an interval of $10{ }^{\circ} \mathrm{C}$ varied from 30 to $80{ }^{\circ} \mathrm{C}$. In all experiments, there was a $100 \%$ conversion of $\mathbf{0}$. On the chromatograms of the total ion current of the mass detector, the oxidation products $\mathbf{0}$ are represented by the same set of overlapping narrow and wide peaks (Figure 4).

The ratio of these peaks strongly depends on T. During the transition from 50 to $60{ }^{\circ} \mathrm{C}$, the proportion of narrow peaks sharply decreases, and the proportion of wide peaks increases. When moving from 70 to $80^{\circ} \mathrm{C}$, on the contrary, the wide peaks disappear and only the narrow peaks remain.

The following narrow peaks were identified from the mass spectra (MS) (retention times ( $\mathrm{min}$ ) according to the chromatogram with $\mathrm{T}=40{ }^{\circ} \mathrm{C}$ ): $1 \mathbf{1 a} 11.91$ (monool 1$\left.\mathrm{Ad}(\mathrm{OH})_{1}\right)$, 1c 12.81, 1d 12.74, 2a 14.23 (diol 1,3-Ad(OH) $)$, 2a' 14.45, 2b 14.78, 3a 16.34 (triol 1,3,5-Ad( $\left.(\mathrm{OH})_{3}\right)$, 4a 18.16 (tetraol 1,3,5,7-Ad(OH) $)_{4}$, 5a 20.29 (pentaol 1,2,3,5,7-Ad(OH) $)$ (Schemes 1, 4 and 5).

In Figure 4, the identified narrow peaks are mainly indicated only on one chromatogram of $40{ }^{\circ} \mathrm{C}$, since at other $\mathrm{T}$, these peaks are similarly located in the chromatograms.

The peaks of tertiary alcohols $\mathrm{Ad}(\mathrm{OH})_{n}, n=1-5$, are the reference ones, since they were used to distinguish chromatograms into regions belonging to different groups of n-oxygenation of $\mathbf{0}$. 

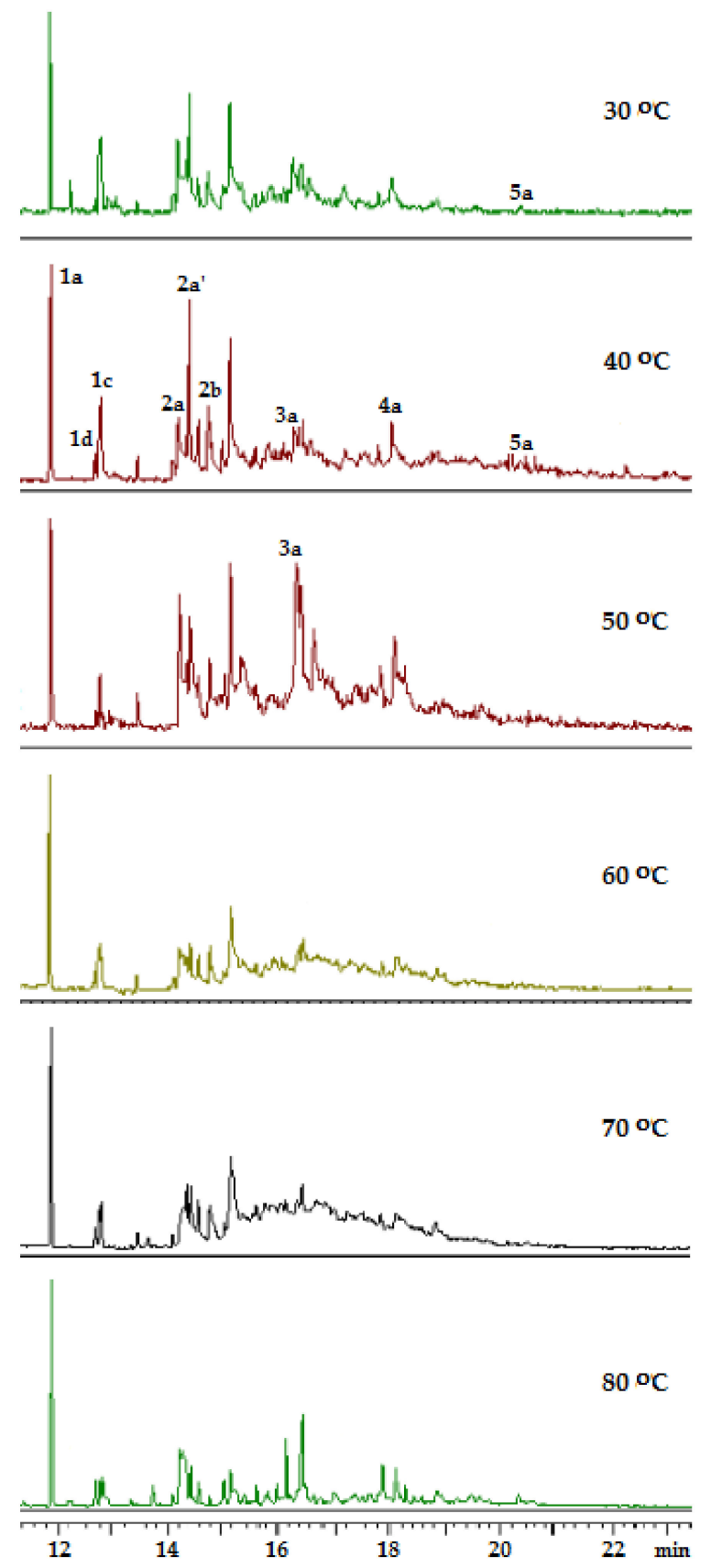

Figure 4. Chromatograms of diethyl ether extracts of reaction mixtures containing oxidation products of 0 obtained by slow drip addition of a $50 \%$ aqueous solution of $\mathrm{H}_{2} \mathrm{O}_{2}$.

In the NIST/EPA/NIH 11,17 databases, reference MS of compounds $3 \mathbf{a}, \mathbf{4 a}$, and $\mathbf{5 a}$ were absent [74]. In the two published MSs of 3a, the intensity of the peak of the molecular ion with $m / z=184\left(\mathrm{M}^{+} \bullet\right)$ is $5-10 \%$, the peak with $m / z=111(31-46 \%)$, the peak with $m / z=127(100 \%)[57,61]$. There are no published MSs of $\mathbf{4 a}$ and $\mathbf{5 a}$.

To find the location of peak $3 \mathbf{a}$, two $\left(40\right.$ and $\left.70{ }^{\circ} \mathrm{C}\right)$ chromatograms of the total ion current (Figure 4) were scanned when setting the $m / z=127$ (Figure 5).

Two groups of peaks were found in the region of retention times of 16 and $18 \mathrm{~min}$ (Figure 5). Presumably, the first group of peaks is due to $\mathbf{0}$ triols, and the second-to 0 tetraols (Scheme 4). Polyols with tertiary positions of hydroxyl groups come out first. Scheme 4 also shows one of the most probable structures of $\mathbf{0}$ tri- and tetrapolyols, each containing one secondary hydroxy group, which are characterized by somewhat longer retention times. 


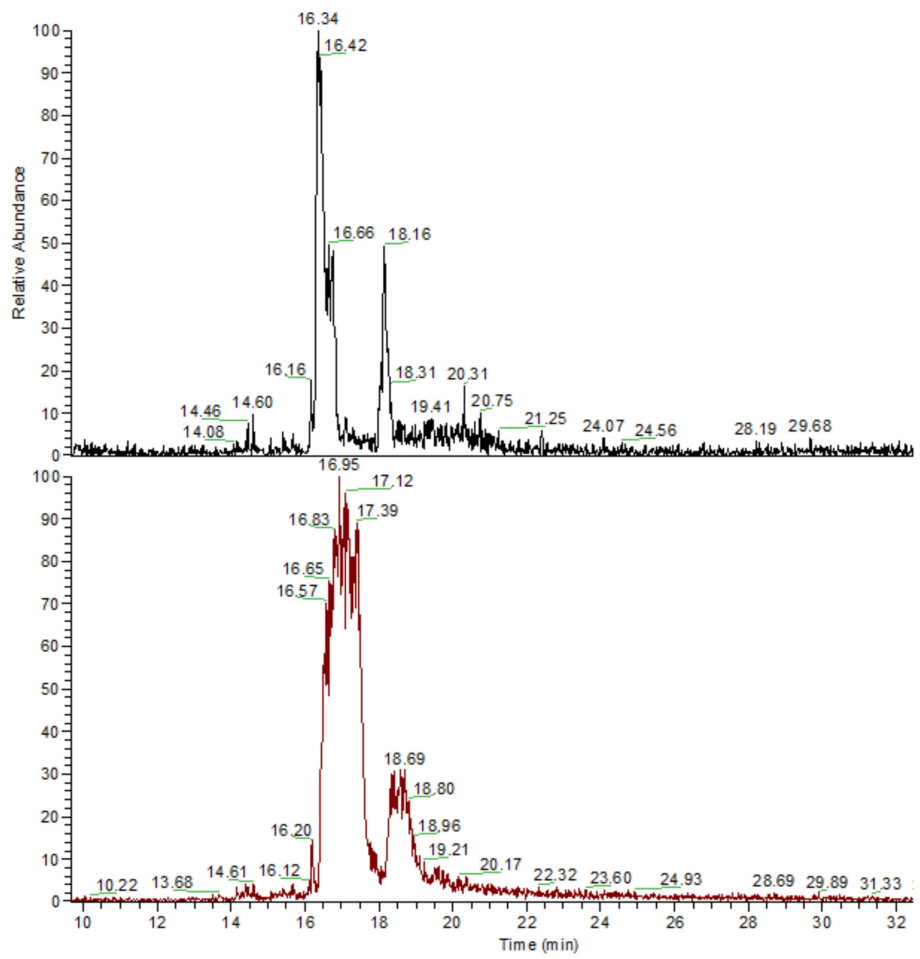

Figure 5. Selected ion ( $\mathrm{m} / \mathrm{z} 127)$ chromatograms: $40{ }^{\circ} \mathrm{C}$ (top), $70{ }^{\circ} \mathrm{C}$ (bottom).

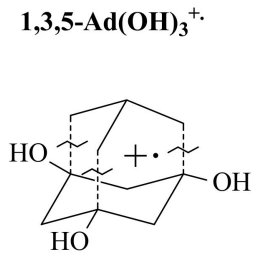

$M^{+}$, m/z $184(5-10 \%)$

(A) $40{ }^{\circ} \mathrm{C} \quad 16.34$

RT, min $\sim 16.83$

(B) $70^{\circ} \mathrm{C}$

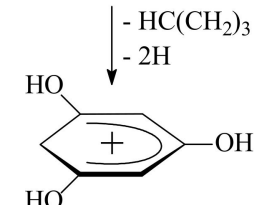

$1,3,5-\mathrm{Bz}(\mathrm{OH})_{3}{ }^{+}$. $\mathrm{m} / \mathrm{z} 127(100 \%)$
$1,3,4-\mathrm{Ad}(\mathrm{OH})_{3}{ }^{+}$

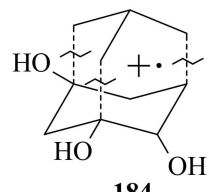

184

16.66

$\sim 17.20$

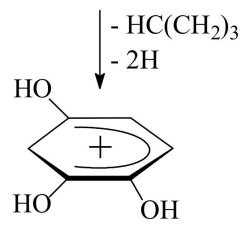

1,2,5-Bz $(\mathrm{OH})_{3}{ }^{+.}$

127

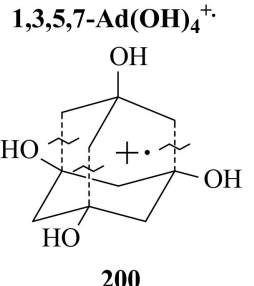

18.16

$\sim 18.69$

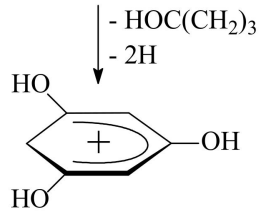

1,3,5-Bz(OH) ${ }_{3}{ }^{+}$

127
$1,3,5,6-\mathrm{Ad}(\mathrm{OH})_{4}{ }^{+}$<smiles>CC1(O)C2(O)CC3CC(O)(C2)CC1(O)C3O</smiles>

200

18.31

$\sim 18.80$

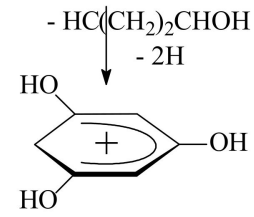

$1,3,5-\mathrm{Bz}(\mathrm{OH})_{3}{ }^{+.}$

127

Scheme 4. Fragmentation of molecular ions of $\mathbf{0}$ tri- and tetraols.

The tetraol 1,3,5,7-Ad(OH) ${ }_{4}$ (4a) molecule contains twelve equivalent secondary $\mathrm{C}-\mathrm{H}$ bonds. In the complete absence of tertiary $\mathrm{C}-\mathrm{H}$ bonds, this makes the $4 \mathrm{a}$ molecule a unique object from the point of view of subsequent oxidation. The only hydroxy product of 1,3,5,7- $\mathrm{Ad}(\mathrm{OH})_{4}$ oxidation is pentaol 1,2,3,5,7-Ad(OH) $)_{5}(5 \mathbf{a})$ (Scheme 5). 


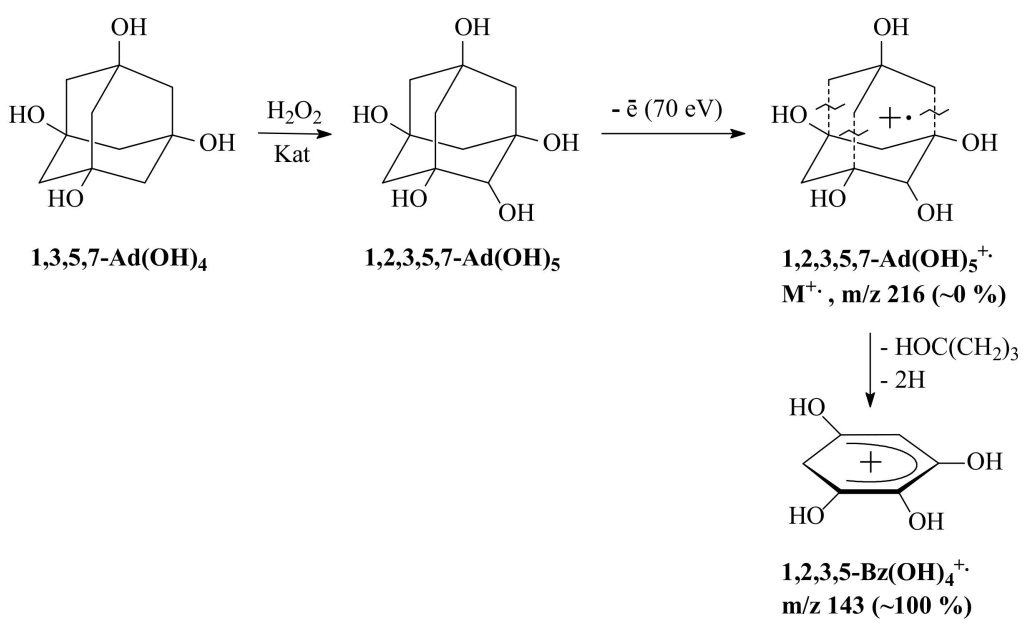

Scheme 5. Fragmentation of the molecular ion of 0 pentaol.

Upon fragmentation of radical cations $1,2,3,5,7-\mathrm{Ad}(\mathrm{OH})_{5}{ }^{+}(\mathrm{m} / \mathrm{z}=216$, the intensity of the molecular ion is about $0 \%$ ), the formation of tetra-hydroxy-substituted benzenium cation $1,2,3,5-\mathrm{Bz}(\mathrm{OH})_{4}{ }^{+}, \mathrm{m} / z=143$ with the highest $(100 \%)$ intensity, was expected (Scheme 5).

In order to search for such an ion, scanning with $m / z=143$ of the two previously described chromatograms of the total ion current (see Figure 4) was set. A low-intensity peak with $\mathrm{m} / z=143$ was found in the chromatogram $40^{\circ} \mathrm{C}$ with a retention time of about $20 \mathrm{~min}$ (Figure 6) and was not detected in the chromatogram $70^{\circ} \mathrm{C}$.

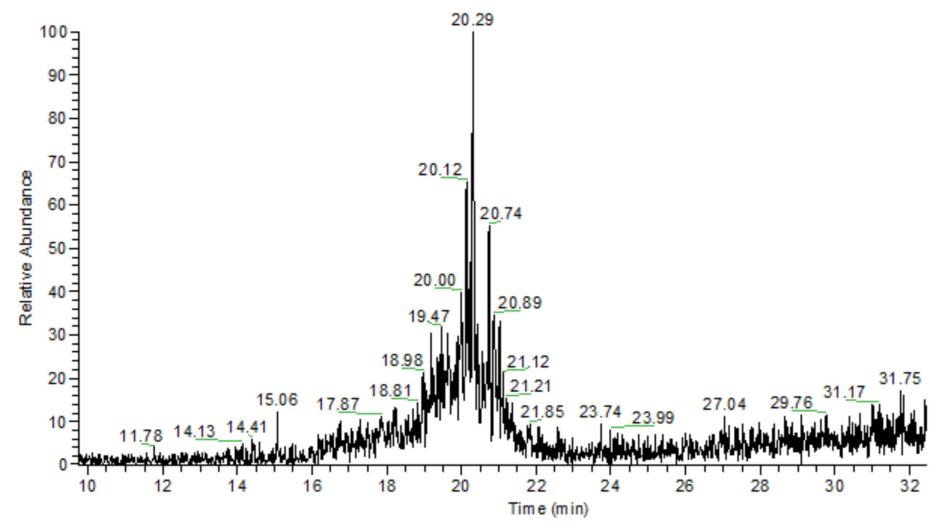

Figure 6. Selected ion $(\mathrm{m} / \mathrm{z} 143)$ chromatogram $40^{\circ} \mathrm{C}$.

Thus, at $40{ }^{\circ} \mathrm{C}$, the 0 oxidation proceeds more " $n$-deeply" ( $\left.n=5\right)$ (Figure 6), but with lower yields of tri- and tetra-oles of $\mathbf{0}$, than at $70^{\circ} \mathrm{C}$ (Figure 5).

As far as is known, this is the first example of the oxidation of 0 to pentaol.

To determine the composition of wide chromatographic peaks (15-21 min, Figure 4), including the regions of tri- and tetra-oles of $\mathbf{0}$, they were scanned with different characteristic values of $\mathrm{m} / \mathrm{z}$. The analysis showed that these chromatographic peaks were formed by the superposition of several peaks, the exact identification of which is impossible.

Therefore, according to the retention times of the peaks of tertiary alcohols $\mathrm{Ad}(\mathrm{OH})_{\mathrm{n}}$, $n=1-5$, all the chromatograms were divided into five regions belonging to different groups of $n$-oxygenation of $\mathbf{0}$.

The highest values of the total outputs of nO-Ad products, $n=1-5$, are achieved at different T: $22 \% 1 \mathrm{O}$-Ad at $80{ }^{\circ} \mathrm{C}, 46 \% 2 \mathrm{O}$-Ad at $30{ }^{\circ} \mathrm{C}, 45 \% 3 \mathrm{O}$-Ad and $25 \% 4 \mathrm{O}$-Ad at $50{ }^{\circ} \mathrm{C}$, $7 \% 5 \mathrm{O}-\mathrm{Ad}$ at $40{ }^{\circ} \mathrm{C}$ (Table 1 ). 
Table 1. The total yields of the five product groups nO-Ad, $n=1-5$, at different reaction temperatures $\mathrm{T}$.

\begin{tabular}{cccccccc}
\hline & \multicolumn{7}{c}{$\mathbf{T},{ }^{\circ} \mathbf{C}$} \\
\cline { 2 - 7 } & $\mathbf{3 0}$ & $\mathbf{4 0}$ & $\mathbf{5 0}$ & $\mathbf{6 0}$ & $\mathbf{7 0}$ & $\mathbf{8 0}$ \\
\cline { 2 - 7 } & & & $\mathbf{\%}$ & & \\
\hline 1 & 20 & 14 & 10 & 9 & 40 & 30 \\
\hline 2 & 46 & 40 & 18 & 36 & 34 & 31 \\
\hline 3 & 26 & 27 & 45 & 35 & 16 & 15 \\
\hline 4 & 8 & 12 & 25 & 18 & 1 & 2 \\
\hline 5 & 0 & 7 & 2 & 2 & & \\
\hline
\end{tabular}

The content of $1 \mathrm{a}$ was $10,7,5,6,6$ and $16 \%$ at $30,40,50,60,70$ and $80^{\circ} \mathrm{C}$, respectively. At $80^{\circ} \mathrm{C}$, there are no wide peaks, the content of narrow peaks $\mathbf{1 a}, \mathbf{2 a}, \mathbf{3 a}, \mathbf{4 a}$, and $\mathbf{5 a}$ is 16,3 , 4,4 , and $1 \%$, respectively, the total content of these tertiary alcohols is $28 \%$.

Thus, when an oxidizer solution is introduced drop-by-drop in the catalytic system, $\mathbf{0}$ is oxidized to a mixture of $n$-oxygenated products with a significant content of tri-, tetra-, and penta-ols at its complete conversion. The total number of nO-Ad products, $n=3-5$, reaches a maximum value of $72 \%$ at $50{ }^{\circ} \mathrm{C}$ (Figure 7 ).

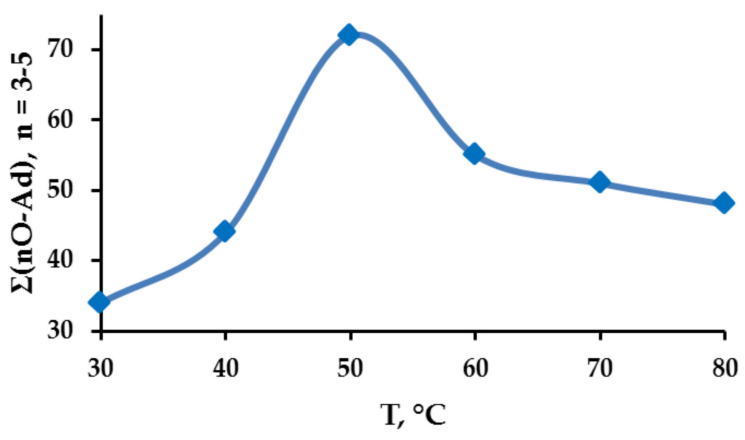

Figure 7. The dependence of the sum of products $\Sigma(\mathrm{nO}-\mathrm{Ad}), n=3-5$, on $\mathrm{T}$.

If the envelopes of the wide peaks on the chromatogram of $50{ }^{\circ} \mathrm{C}$ are taken as the component of the wide peaks on the chromatogram of $70{ }^{\circ} \mathrm{C}$ (Figure 4 ), then at $50{ }^{\circ} \mathrm{C}$, the content of the narrow peaks $1 \mathbf{a}, \mathbf{2 a}, \mathbf{3 a}, \mathbf{4 a}$, and $\mathbf{5 a}$ is $5,4,10,3$ and $0 \%$, respectively, the total content of these tertiary alcohols is $22 \%$ (Figure 4 ). Thus, at $50{ }^{\circ} \mathrm{C}$, the highest yield of $3 \mathbf{a}$ $(10 \%)$ is observed.

\section{Discussion}

3.1. The Dependence of the Conversion (C) 0 on the Volume $V\left(\mathrm{H}_{2} \mathrm{O}_{2}\right)$ of the Fast Introduced Oxidizer Solution: Three Regions with Different Catalytic Activity and the Structure of the Solvent

The conversion $\mathrm{C}$ of 0 and the sums of the products $\Sigma(\mathrm{nO}-\mathrm{Ad}), n=1-4$, depend on the volume $\mathrm{V}\left(\mathrm{H}_{2} \mathrm{O}_{2}\right)$ of the oxidizer solution at a fast method of its introduction (Figure 3). The exact position of the maximum $\mathrm{C}$, which was not experimentally established, was determined by the following method (Figure 8).

If you were to draw a straight line (a) $\mathrm{C}=160 \cdot \mathrm{V}\left(\mathrm{H}_{2} \mathrm{O}_{2}\right)$ through two starting points $(\mathrm{V}(\mathrm{mL}) ; \mathrm{C}(\%))$ : $(0 ; 0)$ and $(0.5 ; 80)$, then $\mathrm{C}=100 \%$ will correspond to the value $\mathrm{V}=0.625 \mathrm{~mL}$. Three points $(0.625 ; 100),(1 ; 86)$ and $(1.5 ; 66)$ fall exactly on the straight line (b) $\mathrm{C}=-40 \cdot \mathrm{V}\left(\mathrm{H}_{2} \mathrm{O}_{2}\right)+126$, and three points $(1.5 ; 66),(2 ; 65)$ and $(10 ; 44)$ fall exactly on the straight line (c) $\mathrm{C}=-2.6044 \cdot \mathrm{V}\left(\mathrm{H}_{2} \mathrm{O}_{2}\right)+70.053$. Thus, the maximum value of $\mathrm{C}=100 \%$ is reached at $\mathrm{V}\left(\mathrm{H}_{2} \mathrm{O}_{2}\right)=0.625 \mathrm{~mL}$, and the entire studied area is divided into three parts $\mathrm{I}$, II, and III (Figure 8). 


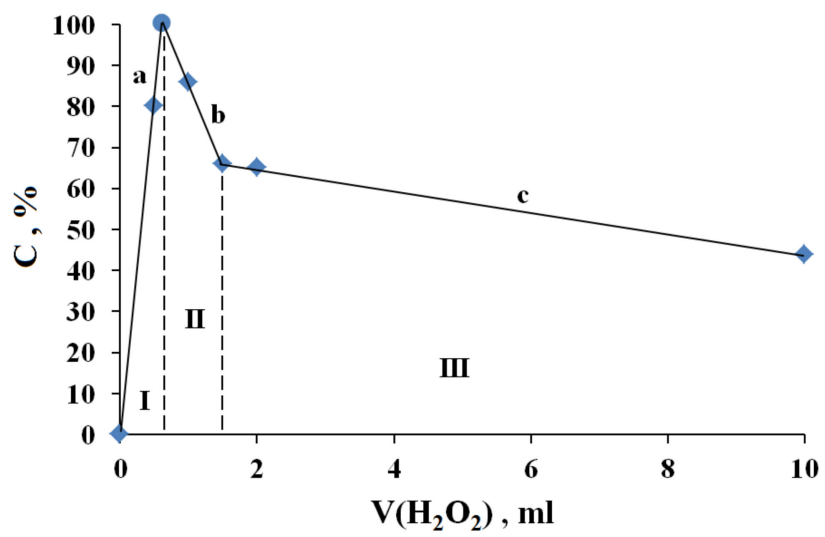

Figure 8. The dependence of $\mathrm{C}$ on $\mathrm{V}\left(\mathrm{H}_{2} \mathrm{O}_{2}\right)$, fast introduction.

Presumably, the presence of a maximum $\mathrm{C}$ at $\mathrm{V}\left(\mathrm{H}_{2} \mathrm{O}_{2}\right)=0.625 \mathrm{~mL}$ is associated with greater stability of the initial $\mathrm{Cu}_{2} \mathrm{Cl}_{4} \cdot 2 \mathrm{DMG}$ complex in region I than in region II.

A critical amount of $\mathrm{H}_{2} \mathrm{O}$ is reached at $\mathrm{V}\left(\mathrm{H}_{2} \mathrm{O}_{2}\right)=0.625 \mathrm{~mL}$, above which $\mathrm{H}_{2} \mathrm{O}$ begins to have a destabilizing effect on the initial $\mathrm{Cu}_{2} \mathrm{Cl}_{4} \cdot 2 \mathrm{DMG}$ complex, apparently accelerating ligand exchange.

In this case, with an increase in $\mathrm{V}\left(\mathrm{H}_{2} \mathrm{O}_{2}\right)$ in region $\mathrm{I}$, an increase in $\mathrm{C}$ can be associated with an increase in the concentration (amount) of the oxidant $\mathrm{H}_{2} \mathrm{O}_{2}$, and in region II with an increase in $\mathrm{V}\left(\mathrm{H}_{2} \mathrm{O}_{2}\right)$, a decrease in $\mathrm{C}$ can be associated with an increase in the rate of ligand exchange, as a result of which the contact time of $\mathbf{0}$ with the catalytic complex $\mathrm{Cu}_{2} \mathrm{Cl}_{4} \cdot 2 \mathrm{DMG}$ and $\mathrm{H}_{2} \mathrm{O}_{2}$ decreases.

In region III, with an increase in $\mathrm{V}\left(\mathrm{H}_{2} \mathrm{O}_{2}\right)$, a further decrease in $\mathrm{C}$ may be associated with almost instantaneous destruction of the initial $\mathrm{Cu}_{2} \mathrm{Cl}_{4} \cdot 2 \mathrm{DMG}$ catalytic complex.

It was found that the values of the maximum at $\mathrm{V}\left(\mathrm{H}_{2} \mathrm{O}_{2}\right)=0.625 \mathrm{~mL}$ and the bend at $\mathrm{V}\left(\mathrm{H}_{2} \mathrm{O}_{2}\right)=1.5 \mathrm{~mL}$ were not random, but were associated with a change in the structure of the solution, which occurs with an increase in the water component.

It is known that water-acetonitrile solutions have a number of unusual properties, which are manifested when analyzing the dependencies of various chemical and physical characteristics of solutions on the ratio of their components (from $100 \% \mathrm{H}_{2} \mathrm{O}$ to $100 \%$ $\mathrm{CH}_{3} \mathrm{CN}$ ) [75-78].

The presence of extreme points and bends on these dependencies indicates the ratios of the molecules of the two components, at which their sufficiently stable associates (complexes) are formed.

To compare the obtained results (Figure 8) with the data on the structure of binary solvents, the values of the characteristics of the three solutions used in these studies were calculated [75-78], based on the volume ratios of the oxidizer (Ox) and the solvent (An) (Table 2).

The maximum $\mathrm{C}$ at $\mathrm{V}\left(\mathrm{H}_{2} \mathrm{O}_{2}\right)=0.625 \mathrm{~mL}$ (Figure 8) corresponds to the ratio of 4.4:1 molecules of acetonitrile and an aqueous solution of the oxidizer.

The formation of heteroassociates of $\mathrm{CH}_{3} \mathrm{CN}$ and $\mathrm{H}_{2} \mathrm{O}$ molecules of the composition $1: 1,2: 1$, and $4.5: 1$, respectively, at $\mathrm{X}(\mathrm{AN})=50,67$, and $90 \mathrm{wt} \%$ of $\mathrm{CH}_{3} \mathrm{CN}$ in binary solutions at $25{ }^{\circ} \mathrm{C}$ was established by ${ }^{1} \mathrm{H}$ NMR and chemometry methods in combination with quantum chemical calculations [76,77]. Based on quantum chemical calculations for a 4.5:1 heteroassociate, structural models of the association of one $\mathrm{H}_{2} \mathrm{O}$ molecule with four and five $\mathrm{CH}_{3} \mathrm{CN}$ molecules are proposed [77]. 
Table 2. The ratio of the main components of water-acetonitrile solutions of three reaction mixtures.

\begin{tabular}{cccccc}
\hline V, mL & AN ** & & $\begin{array}{c}\text { X(AN), } \\
\text { wt\% }\end{array}$ & $\begin{array}{c}\text { Y(AN), } \\
\text { mol Fraction }\end{array}$ & $\begin{array}{c}\text { N(AN): N(Ox), } \\
\text { AN Molecules: } \\
\text { Ox Molecules }\end{array}$ \\
\hline 0.625 & 8 & 91 & 0.81 & $4.4: 1$ \\
\hline 1.5 & 8 & 80 & 0.65 & $1.8: 1$ \\
\hline 10 & 10 & 43 & 0.25 & $1: 2.9$ \\
\hline
\end{tabular}

* $50 \% \mathrm{H}_{2} \mathrm{O}_{2}, \mathrm{H}_{2} \mathrm{O}$ and $\mathrm{H}_{2} \mathrm{O}_{2}(1: 1), \mathrm{d}(\mathrm{Ox}) \approx \mathrm{d}\left(\mathrm{H}_{2} \mathrm{O}\right)=0.9881 \mathrm{~g} / \mathrm{cm}^{3}$ at $50{ }^{\circ} \mathrm{C}, \mathrm{M}(\mathrm{Ox})=18.5 \mathrm{~g} / \mathrm{mol}^{* *} \mathrm{CH}_{3} \mathrm{CN}$ $\mathrm{d}\left(\mathrm{CH}_{3} \mathrm{CN}\right)=0.7473 \mathrm{~g} / \mathrm{cm}^{3}$ at $50{ }^{\circ} \mathrm{C}, \mathrm{M}\left(\mathrm{CH}_{3} \mathrm{CN}\right)=41 \mathrm{~g} / \mathrm{mol}$.

Thus, the achievement of the maximum $\mathrm{C}$ at $\mathrm{V}\left(\mathrm{H}_{2} \mathrm{O}_{2}\right)=0.625 \mathrm{~mL}$ (Figure 8) can be associated with the formation of heteroassociates with a ratio of 4.4:1 of acetonitrile molecules and molecules of an aqueous solution of the oxidizer.

This means that water molecules introduced into the acetonitrile solution up to the value $\mathrm{V}\left(\mathrm{H}_{2} \mathrm{O}_{2}\right)=0.625 \mathrm{~mL}$ remain in the solution and most of the time do not enter the coordination sphere of copper ions of the catalytic complex, which ensures its increased stability.

This assumption is consistent with the data on the solubility of $\mathrm{CuCl}_{2}$ in aqueous acetonitrile solutions at $25{ }^{\circ} \mathrm{C}$ [78]. It was found that the entire studied range of values $\mathrm{Y}(\mathrm{AN})=0-1 \mathrm{~mol}$ fraction was divided into four regions with different ratios of solvate components: (1) $\mathrm{CuCl}_{2} \cdot 2 \mathrm{H}_{2} \mathrm{O}$ at $\mathrm{Y}(\mathrm{AN})=0-0.15$, (2) $\mathrm{CuCl}_{2} \cdot 2 \mathrm{H}_{2} \mathrm{O} \cdot \mathrm{CH}_{3} \mathrm{CN}$ at $\mathrm{Y}(\mathrm{AN})=0.15-0.3,(3) \mathrm{CuCl}_{2} \cdot 3 \mathrm{H}_{2} \mathrm{O} \cdot 2 \mathrm{CH}_{3} \mathrm{CN}$ at $\mathrm{Y}(\mathrm{AN})=0.3-0.6$ and (4) $\mathrm{CuCl}_{2} \cdot 1.5 \mathrm{CH}_{3} \mathrm{CN}$ at $\mathrm{Y}(\mathrm{AN})=0.6-1[78]$.

Region I of this study completely falls into the region (4) [78], in which $\mathrm{H}_{2} \mathrm{O}$ molecules are not part of the $\mathrm{CuCl}_{2}$ solvate. The transition from region II to III occurs at $\mathrm{Y}(\mathrm{AN})=0.65$, which is close to $Y(A N)=0.6$ transition from the region (4) to (3) [78], as a result of which $\mathrm{H}_{2} \mathrm{O}$ molecules appear in the $\mathrm{CuCl}_{2}$ solvate. With this transition, the relative amount of the $\mathrm{H}_{2} \mathrm{O}$ molecule in the solvate immediately (abruptly) becomes one and a half times greater than the number of $\mathrm{CH}_{3} \mathrm{CN}$ molecules.

At the transition point from region II to III, the value of $\mathrm{N}(\mathrm{AN}): \mathrm{N}(\mathrm{Ox})=1.8: 1\left(50{ }^{\circ} \mathrm{C}\right)$ is close to the value of $2: 1$ of the $2 \mathrm{CH}_{3} \mathrm{CN} \cdot 1 \mathrm{H}_{2} \mathrm{O}$ heteroassociate, the formation of which at $25^{\circ} \mathrm{C}$ was recorded at $\mathrm{X}(\mathrm{AN})=67 \mathrm{wt} \%[76,77]$.

Taking into account rounding, one can assume that region III (Y(AN) $=0.25-0.65 \mathrm{~mol}$ fraction) of the study fully corresponds to the region (3) $(\mathrm{Y}(\mathrm{AN})=0.3-0.6 \mathrm{~mol}$ fraction) of the study of solvates [78].

In all regions (I-III), the amounts of substrate and catalyst molecules are minimal compared to the amounts of solvent molecules and the added aqueous solution molecules of the oxidizer. After substitution of DMG molecules in the complex with $\mathrm{CH}_{3} \mathrm{CN}$ molecules as a result of ligand exchange, one can obtain almost the same chemical system consisting of $\mathrm{CuCl}_{2}, \mathrm{H}_{2} \mathrm{O}\left(\mathrm{H}_{2} \mathrm{O}_{2} \approx \mathrm{H}_{2} \mathrm{O}\right)$, and $\mathrm{CH}_{3} \mathrm{CN}$ as in the work on solvates [78]. The proximity of the chemical composition of the solutions explains the coincidence of the intervals $\mathrm{Y}$ (AN) of the two works.

Thus, the catalytic activity of the system under study and the type of dependence of $\mathrm{C}$ on $\mathrm{V}\left(\mathrm{H}_{2} \mathrm{O}_{2}\right)$ (Figure 8 ) is determined by the structure of the water-acetonitrile solution, which changes with an increase in the amount of $\mathrm{V}\left(\mathrm{H}_{2} \mathrm{O}_{2}\right)$ solution of the oxidizer introduced.

\subsection{Comparison of the Results of the Authors' and Other Methods of 0 Oxidation Described in the Literature}

Based on the above analysis, with a fast $(\sim 3 \mathrm{~s})$ method of introducing an oxidizer solution into the reaction volume, the oxidation depth of $\mathbf{0}$ was small due to the impossibility of simultaneous implementation of two oppositely acting factors, each of which separately contributes to an increase in the oxidation depth. 
The first factor: for the maximum possible contact time of $\mathbf{0}$ with the initial catalytic complex $\mathrm{Cu}_{2} \mathrm{Cl}_{4} \cdot 2 \mathrm{DMG}$, the introduced amount of $\mathrm{H}_{2} \mathrm{O}$ should be minimal. The second factor: the amount of the oxidizer $\mathrm{H}_{2} \mathrm{O}_{2}$ should be the maximum possible, but with its increase, the amount of water introduced increases (the oxidizer is a $50 \%$ aqueous solution of $\mathrm{H}_{2} \mathrm{O}_{2}$ ).

It is for the implementation of such conditions that a slow $(60 \mathrm{~min})$ drop-by-drop method of introducing the oxidizer solution was chosen. With this method of oxidation of $\mathbf{0}$, the possible contact time of $\mathbf{0}$ with the initial catalytic complex $\mathrm{Cu}_{2} \mathrm{Cl}_{4} \cdot 2 \mathrm{DMG}$ in combination with $\mathrm{V}\left(\mathrm{H}_{2} \mathrm{O}_{2}\right)=1 \mathrm{~mL}$ from region II was maximized. The value $\mathrm{V}\left(\mathrm{H}_{2} \mathrm{O}_{2}\right)=1 \mathrm{~mL}$ slightly exceeded the value $\mathrm{V}\left(\mathrm{H}_{2} \mathrm{O}_{2}\right)=0.625 \mathrm{~mL}$ that was critical for the quick method of introducing the oxidizer solution.

The results achieved can be compared with the literature data (Table 3, Scheme 6) [57-63], [58]-review.

Table 3. One-stage synthesis of 3a and $4 \mathbf{a}$.

\begin{tabular}{|c|c|c|c|c|c|c|c|c|c|c|c|}
\hline \multirow{2}{*}{ Sub } & \multicolumn{4}{|c|}{ Products, $\%$} & \multirow{2}{*}{$\mathrm{C}, \%$} & \multirow{2}{*}{ Ox } & \multirow{2}{*}{ Cat } & \multirow{2}{*}{ Sol } & \multirow{2}{*}{$\begin{array}{l}{ }^{\circ} \mathrm{C} \\
{ }^{\circ}\end{array}$} & \multirow{2}{*}{$\begin{array}{l}\text { t, } \\
h\end{array}$} & \multirow{2}{*}{ Ref. } \\
\hline & $1 \mathrm{a}$ & $2 a$ & $3 a$ & $4 a$ & & & & & & & \\
\hline 0 & 10 & 53 & & & $>99$ & \multirow{4}{*}{$\mathrm{O}_{2}$} & \multirow{3}{*}{$\begin{array}{c}\mathrm{NHPI} / \\
\mathrm{Co}(\text { acac })_{2}\end{array}$} & \multirow{4}{*}{$\mathrm{AcOH}$} & \multirow{3}{*}{75} & 6 & \multirow{3}{*}{ [60] } \\
\hline $1 \mathrm{a}$ & & 76 & 18 & & 95 & & & & & 15 & \\
\hline $2 a$ & & & 85 & & 46 & & & & & 24 & \\
\hline $2 a$ & & 42 & 56 & & 100 & & $+\mathrm{MnO}_{2}$ & & 60 & 30 & [61] \\
\hline 0 & & & 42 & & n.r. & \multirow{2}{*}{\multicolumn{2}{|c|}{$\mathrm{CrO}_{3}$}} & $+\mathrm{H}_{2} \mathrm{SO}_{4}$ & 80 & 3 & [62] \\
\hline 0 & & & $50 *$ & & n.r. & & & $\mathrm{AcOH}$ & 100 & $>1$ & {$[63]$} \\
\hline \multirow{2}{*}{0} & & & 90 & & 98 & \multirow{2}{*}{\multicolumn{2}{|c|}{$\mathrm{O}_{2} \mathrm{C}\left(\mathrm{CF}_{3}\right) \mathrm{CH}_{3}$}} & \multirow{2}{*}{$\mathrm{CH}_{2} \mathrm{Cl}_{2} / \mathrm{TFP}(2: 1)$} & \multirow{2}{*}{-20} & 2 & \multirow{2}{*}{ [57] } \\
\hline & & & & 78 & n.r. & & & & & 3 & \\
\hline 0 & 2 & 12 & 32 & & 46 & \multirow[b]{2}{*}{$\mathrm{H}_{2} \mathrm{O}_{2}$} & $\mathrm{Fe}(\mathrm{III})^{* *}$ & \multirow[b]{2}{*}{$\mathrm{CH}_{3} \mathrm{CN}$} & 25 & 5 & [59] \\
\hline 0 & 5 & 4 & 10 & 3 & 100 & & $\begin{array}{l}\mathrm{Cu}_{2} \mathrm{Cl}_{4} \\
2 \mathrm{DMG}\end{array}$ & & 50 & 1 & $* * *$ \\
\hline
\end{tabular}

* isolated product; ${ }^{* *} \mathrm{Fe}^{\mathrm{III}}$-dpaq ${ }^{\mathrm{R}}-\left[\mathrm{D}_{4}\right], \mathrm{R}=\mathrm{NO}_{2} ;{ }^{* * *}$ this work.<smiles>CCCCCC(=O)OOC1(C)OO1</smiles>

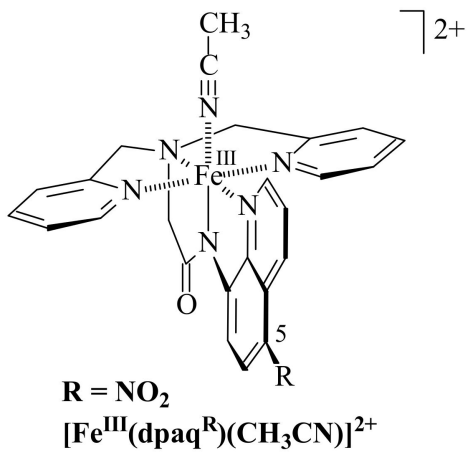

Scheme 6. Oxidants and catalytic complex for one-stage synthesis of $\mathbf{3 a}$ and $\mathbf{4 a}$.

The use of $\mathrm{O}_{2}$ as an oxidizer does not allow the single-stage oxidation of $\mathbf{0}$ to 3a and $\mathbf{4 a}$, but can be used for this purpose when implementing a multi-stage synthesis strategy $[60,61]$.

$\mathrm{CrO}_{3}$ is effective in single-stage oxidation of $\mathbf{0}$ to $3 \mathbf{a}[62,63]$. Apparently, this oxidizer can be used for deeper oxidation of $\mathbf{0}$ to $4 \mathbf{a}$.

The oxidation of $\mathbf{0}$ with $\mathrm{O}_{2} \mathrm{C}\left(\mathrm{CF}_{3}\right) \mathrm{CH}_{3}$ demonstrates the unique properties of this system, which is out of competition, potentially capable of oxidizing $\mathbf{0}$ not only to $4 \mathrm{a}$ but also to $\mathbf{5 a}$ with high yields with an increase in reaction time $[57,58]$. 
The results obtained (3a 10\%) are comparable to the yield of 3a 32\% under 0 oxidation conditions close to those discussed in this paper in the presence of a specially synthesized $\mathrm{Fe}(\mathrm{III})$ complex with increased stability when exposed to the $\mathrm{H}_{2} \mathrm{O}_{2}$ oxidizer [59].

It is interesting to note that in the last two works cited, oxidation with $\mathrm{O}_{2} \mathrm{C}\left(\mathrm{CF}_{3}\right) \mathrm{CH}_{3}$ and $\mathrm{H}_{2} \mathrm{O}_{2}$ was carried out with their slow gradual introduction into the reaction mixture, which, in the light of the above analysis, undoubtedly contributed to achieving high yields of the target products.

\subsection{General Regularity in the Fragmentation of Molecular Ions $\mathrm{Ad}(\mathrm{OH})_{n}^{+\bullet}, n=0-4$}

In the $\mathrm{Ad}(\mathrm{OH})_{\mathrm{n}}$ series $(n=0-4)$, the MS of 0 occupies a special position $[57,61,74,79,80]$. The molecular peak $\left(\mathrm{M}^{+\bullet}\right)$ with $\mathrm{m} / z=136$ has the highest $(100 \%)$ intensity, and the peak of the benzenium cation $\left(\mathrm{C}_{6} \mathrm{H}_{7}{ }^{+}\left(\mathrm{Bz}^{+}\right)\right)$(protonated benzene [81-84]) with $\mathrm{m} / \mathrm{z}=79$ has the second highest $(74 \%)$ intensity (Scheme $\left.7, X_{n}=H, O H\right)[74]$.

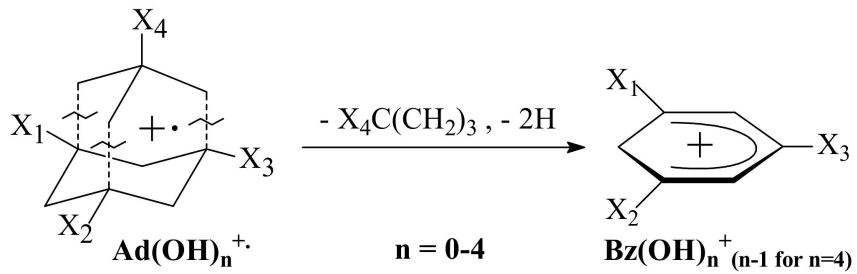

Scheme 7. The main channel of fragmentation of $\mathbf{0 , 1 a}, \mathbf{2 a}, \mathbf{3 a}, \mathbf{4 a}$ molecular ions.

The other eight most intense peaks also have a fairly high relative abundance in the MS of 0 (m/z (rel.int., \%)): 136 (99.9), 135 (33.5), 94 (32.3), 93 (66.2), 80 (41.7), 79 (74.4), 77 (27.7), 67 (31.4), 41 (24.2), 39 (25.5) [74]. The pathways of fragmentation $\mathrm{M}^{+\bullet} 0$ under MS conditions were analyzed in the studies $[79,80]$.

Going from 0 to $1 \mathrm{a}\left(\mathrm{Ad}(\mathrm{OH})_{1}\right)$ in MS, the ratio of the intensities of the peaks with $m / z=152\left(\mathrm{M}^{+\bullet}\right)$ and the main fragmentation ion with $m / z=95\left(\mathrm{Bz}(\mathrm{OH})_{1}{ }^{+}\right)$of $21 \%: 100 \%$, respectively, becomes opposite, and the intensities of the other eight most intense peaks become small (4-11\%). In MS 1-ol 1a, the ten most intense peaks are as follows $(\mathrm{m} / \mathrm{z}$ (rel.int., \%)): 152 (21.4 (M+•)), 109 (4.5), 96 (8.4), 95 (99.9), 94 (10.5), 79 (5.1), 77 (4.7), 67 (3.7), 41 (6.8), 39 (4.8) [74]. This indicates a high selectivity of one channel of fragmentation of the molecular ion $\mathrm{Ad}(\mathrm{OH})_{\mathrm{n}}{ }^{+\bullet}(n=1)$ (Scheme 7$)$.

The same selectivity of molecular ion fragmentation is retained for 1,3 -diol $\mathbf{2 a}\left(\mathrm{Ad}(\mathrm{OH})_{2}\right)$ and 1,3,5-triol 3a $\left(\mathrm{Ad}(\mathrm{OH})_{3}\right)$.

The MS of $\mathbf{2} \mathbf{a}$ is as follows $\left(\mathrm{m} / \mathrm{z}\right.$ (rel.int., \%)): $168\left(14.1\left(\mathrm{M}^{+\bullet}\right)\right), 112(14.4), 111(99.9), 110$ (8.7), 96 (10.8), 81 (8.8), 55 (10.7), 42 (8.9), 43 (26.1), 41 (17.1) [74].

The MS of 3a was described in two papers in 1990 and 2015 as a set of $\mathrm{m} / \mathrm{z}$ (rel.int., \%) [57,61]. The first one reported that the MS of 3a was: $184\left(5\left(\mathrm{M}^{+\bullet}\right)\right), 128(8)$, 127 (100), 111 (31), 110 (10), 109 (10), 85 (7), 69 (8), 55 (7), 43 (36), 41 (12), 39 (9), published for the first time [57]. In the second paper, the following MS of 3a is given: $184\left(10\left(\mathrm{M}^{+\bullet}\right)\right)$, 166 (6), 150 (50), 127 (100), 111 (46), 92 (28) [61].

In both published MSs of 3a, the peak with $m / z=127$ has the highest (100\%) intensity, the peak with $m / z=111(31-46 \%)$, and the intensity of the molecular ion with $m / z=184$ is 5-10\% (average 7.5\%).

There is no published MS of 1,3,5,7-tetraol 4a $\left(\mathrm{Ad}(\mathrm{OH})_{4}\right)$.

The intensities (I) of the peak of the molecular ion $\left(\mathrm{M}^{+\bullet}\right)$ relative to the intensities of the main fragment ions $(100 \%)$ for the $\mathrm{Ad}(\mathrm{OH})_{\mathrm{n}}$ compounds, where $n=1-3$, decrease linearly with increasing $n$ (Scheme 7, Table 4, Figure 9). The resulting equation $\mathrm{I}=-6.75 \mathrm{n}+27.667$, $\mathrm{R}^{2}=0.9995$, allows making estimates $\mathrm{I}=27.667$ and $0.667 \%$, respectively, for the values $n=0$ and 4 . 
Table 4. Relative intensities of peaks of molecular and main fragmentation ions in electron ionization $(70 \mathrm{eV})$ mass spectra of compounds $\mathrm{Ad}(\mathrm{OH})_{\mathrm{n}}, n=0-4[57,61,74]$.

\begin{tabular}{|c|c|c|c|c|c|c|c|c|c|}
\hline \multicolumn{2}{|c|}{$\operatorname{Ad}(\mathrm{OH})_{\mathrm{n}}$} & \multirow{2}{*}{$X_{1}$} & \multirow{2}{*}{$X_{2}$} & \multirow{2}{*}{$X_{3}$} & \multirow{2}{*}{$X_{4}$} & \multicolumn{2}{|c|}{$\mathbf{M}^{+}$} & \multicolumn{2}{|c|}{$\mathrm{Bz}(\mathrm{OH}) \mathrm{n}^{+}$} \\
\hline No. & $\mathrm{n}$ & & & & & $\mathrm{m} / \mathrm{z}$ & $\%$ & $m / z$ & $\%$ \\
\hline \multirow{2}{*}{0} & \multirow{2}{*}{0} & \multirow{2}{*}{$\mathrm{H}$} & \multirow{2}{*}{$\mathrm{H}$} & \multirow{2}{*}{$\mathrm{H}$} & \multirow{2}{*}{$\mathrm{H}$} & \multirow{2}{*}{136} & 100 & \multirow{2}{*}{79} & 74 \\
\hline & & & & & & & $28 *$ & & $100 *$ \\
\hline $1 \mathrm{a}$ & 1 & $\mathrm{OH}$ & $\mathrm{H}$ & $\mathrm{H}$ & $\mathrm{H}$ & 152 & 21 & 95 & 100 \\
\hline $2 a$ & 2 & $\mathrm{OH}$ & $\mathrm{OH}$ & $\mathrm{H}$ & $\mathrm{H}$ & 168 & 14 & 111 & 100 \\
\hline $3 a$ & 3 & $\mathrm{OH}$ & $\mathrm{OH}$ & $\mathrm{OH}$ & $\mathrm{H}$ & 184 & 7.5 & 127 & 100 \\
\hline $4 a$ & 4 & $\mathrm{OH}$ & $\mathrm{OH}$ & $\mathrm{OH}$ & $\mathrm{OH}$ & 200 & $\sim 1^{* *}$ & $127^{* * *}$ & 100 ** \\
\hline
\end{tabular}

* The sum of the intensities of the nine most intense peaks of fragmentation ions given in the MS database is taken as $100 \%$ [74]. ${ }^{* *}$ The authors' estimate by the equation $0.667\left(\mathrm{M}^{+\bullet}\right)$ and $100 \%\left(\mathrm{Bz}(\mathrm{OH})_{\mathrm{n}}{ }^{+}\right), n=4{ }^{* * *} \mathrm{Bz}(\mathrm{OH})_{\mathrm{n}-1}{ }^{+}$ (see Scheme 7).

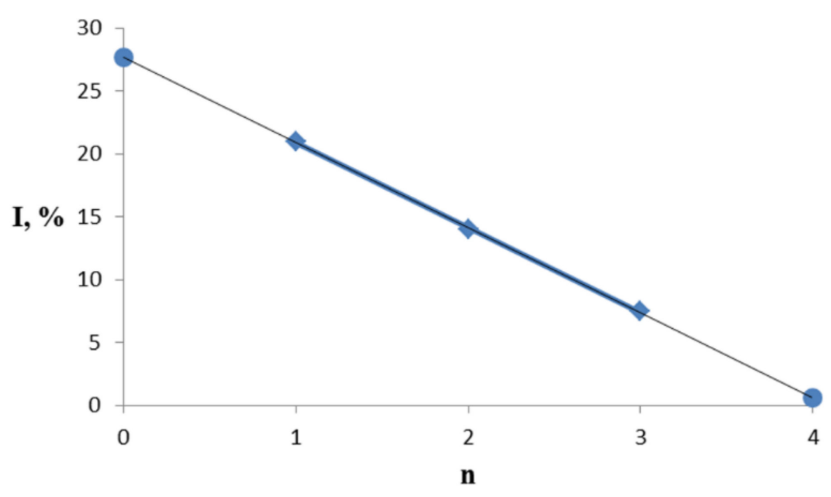

Figure 9. Correlation of the relative intensity I of the molecular ion $\mathrm{Ad}(\mathrm{OH})_{\mathrm{n}}{ }^{+\bullet}$ and the number $n=0-4$ of hydroxyl groups introduced into the tertiary positions of 0 : experimental data for $n=1-3$ and the authors' estimates for $n=0,4$.

Due to the high fragmentation selectivity of $\mathrm{M}^{+\bullet}\left(\mathrm{Ad}(\mathrm{OH})_{\mathrm{n}}{ }^{+\bullet}, n=1-4\right)$ in one channel (Scheme 7), the value of I can be considered as an indicator of the stability of $\mathrm{M}^{+\bullet}$. Therefore, in the case of $\mathbf{0}$, the indicator of the stability of $\mathrm{M}^{+\bullet}$ is its intensity (99.9\%) relative to the sum of all fragment ions (356.9\%). In terms of the accepted relative scale, this gives, respectively, the intensity $\mathrm{I}=28 \%\left(\mathrm{M}^{+\bullet}\right)$ relative to $100 \%$ of the sum of all fragment ions (Table 4, Figure 9).

The two estimates $\mathrm{I}=27.667$ and $28 \%$ made by different methods practically coincide, which indicates the unity of the mechanisms of fragmentation processes $\mathrm{M}^{+\bullet} \mathrm{Ad}(\mathrm{OH})_{\mathrm{n}}$, where $n=0-4$, in one channel (Scheme 7). The basis of this mechanism is the activation (weakening and lengthening) of three co-directed $\mathrm{C}-\mathrm{C}$ bonds of the adamantane ring, which occurs upon single ionization of the starting compounds of this series (Scheme 7).

Since I and $n$ are correlated, it can be assumed that both articles of 1990 and 2015 describe the MS of $3 \mathbf{a}$, and the differences are associated with the presence of impurities in the second case $[57,61]$. So in the article of 2015 , in the MS of $3 \mathbf{a}\left(\mathrm{m} / z=184\left(10 \%, \mathbf{M}^{+\bullet}\right)\right)$, there is a rather intense peak with $m / z=150(50 \%)$. The appearance of such an ion cannot be associated with the fragmentation of $\mathrm{M}^{+} \bullet$ by the successive release of two $\mathrm{OH}$ radicals $(m / z=184-150=34=2 \cdot 17)$, since such a process, even with the release of one OH radical, is not typical for $\mathbf{0}$ alcohols [74].

From the formal point of view, the peak with $\mathrm{m} / \mathrm{z}=150(50 \%)$ can be associated either with the fragmentation of the hydroperoxide group in the secondary position $\left(184\left(\mathrm{M}^{+\bullet}\right)-34\left(\mathrm{H}_{2} \mathrm{O}_{2}\right)=150\right)$ or with the fragmentation of 0 diol containing the secondary $\mathrm{OH}$ group $\left(168\left(\mathrm{M}^{+\bullet}\right)-18\left(\mathrm{H}_{2} \mathrm{O}\right)=150\right)$. For example, in the MS of 2,4- and 2,6-adamantane diols $\left(m / z=168\left(\mathrm{M}^{+\bullet}\right)\right)$, the most intense peak is with $m / z=150(100 \%)$ [74]. 
The authors believe that MS of $4 \mathbf{a}$ is a single peak with $m / z=127(100 \%)$, since the expected intensity I of the molecular ion $\left(m / z=200\left(\mathrm{M}^{+\bullet}\right)\right)$ peak is $0-1 \%$ and there is the only one highly selective channel of fragmentation $\mathrm{M}^{+\bullet}$-breaking the adamantane ring along its three codirectional $\mathrm{C}-\mathrm{C}$ bonds, activated by a single ionization (Scheme 7).

\section{Materials and Methods}

The complex $\mathrm{Cu}_{2} \mathrm{Cl}_{4} \cdot 2 \mathrm{DMG}$ of copper dichloride $\left(\mathrm{CuCl}_{2}\right)$ with dimethylglyoxime (DMG) was synthesized in ethanol according to the technique [71].

A $50 \%$ aqueous solution of $\mathrm{H}_{2} \mathrm{O}_{2}$ (Sigma-Aldrich, St. Louis, MI, USA) was used. 0 had a purity of at least 99\% (Fluka, Buchs, Switzerland). Acetonitrile was qualified for HPLC (Sigma-Aldrich).

$\mathbf{0}$ was oxidized in a glass thermostated reactor equipped with a jacket and reflux condenser with stirring on a magnetic stirrer. The reaction temperature was $50{ }^{\circ} \mathrm{C}$ unless otherwise specified. In all the experiments, the catalyst $\mathrm{Cu}_{2} \mathrm{Cl}_{4} \cdot 2 \mathrm{DMG}$ was brought in immediately before adding the oxidizer solution.

Upon the fast method $(\sim 3 \mathrm{~s})$ of oxidizer solution introduction, the following ratio of reagents was used: $8 \mathrm{~mL}$ of $\mathrm{CH}_{3} \mathrm{CN}, 30 \mathrm{mg}$ of $\mathrm{C}_{10} \mathrm{H}_{16}$, and $30 \mathrm{mg}$ of $\mathrm{Cu}_{2} \mathrm{Cl}_{4} \cdot 2 \mathrm{DMG}$, when varying the amount of $0.5-2 \mathrm{~mL}$ of an oxidizing solution-a $50 \%$ aqueous solution of $\mathrm{H}_{2} \mathrm{O}_{2}$. Samples were taken after 5,30 , and $60 \mathrm{~min}$ of reaction time.

When the amount of $\mathrm{H}_{2} \mathrm{O}_{2}$ solution was increased to $10 \mathrm{~mL}$, the ratio of components was used: $10 \mathrm{~mL}$ of $\mathrm{CH}_{3} \mathrm{CN}, 100 \mathrm{mg}$ of $\mathrm{C}_{10} \mathrm{H}_{16}$, and $20 \mathrm{mg}$ of $\mathrm{Cu}_{2} \mathrm{Cl}_{4} \cdot 2 \mathrm{DMG}$. The reaction time was $30 \mathrm{~min}$.

$\mathbf{0}$ conversion and the ratio of its oxidation products were calculated from the areas of chromatographic peaks obtained on a gas chromatograph (Chystallux 4000 M, Russia) equipped with a flame ionization detector. The column was $30 \mathrm{~m}$ long with an inner diameter of $0.25 \mathrm{~mm}$, the stationary liquid phase SPB was OCTYL (Supelco), the carrier gas was helium. The temperature programming mode of column heating is as follows: isotherm at $60{ }^{\circ} \mathrm{C}-5 \mathrm{~min}$, from 60 up to $260{ }^{\circ} \mathrm{C}$-warming up with a speed of $5^{\circ} / \mathrm{min}$, isotherm at $260^{\circ} \mathrm{C}-10 \mathrm{~min}$. To determine the conversion of $\mathbf{0}$, a precisely measured amount of toluene was introduced into the sample.

Upon the slow method (drop-by-drop) of oxidizer solution introduction, the following ratio of reagents was used: $8 \mathrm{~mL}$ of $\mathrm{CH}_{3} \mathrm{CN}, 30 \mathrm{mg}$ of $\mathrm{C}_{10} \mathrm{H}_{16}$, and $30 \mathrm{mg}$ of $\mathrm{Cu}_{2} \mathrm{Cl}_{4} \cdot 2 \mathrm{DMG}$, $1 \mathrm{~mL}$ of a $50 \%$ aqueous solution of $\mathrm{H}_{2} \mathrm{O}_{2}$. The total reaction time was $60 \mathrm{~min}$ : drop-by-drop adding of oxidizer solution-55 $\mathrm{min}$, holding the reaction mixture- $5 \mathrm{~min}$. The reaction temperature was varied from 30 to $80{ }^{\circ} \mathrm{C}$.

The structure and composition of the $\mathbf{0}$ oxidation products were determined in the diethyl extract using gas chromatography-mass spectrometry on a Finnigan MAT 95 XL instrument. A capillary column Varian VF-5ms was used: length $30 \mathrm{~m}$, inner diameter $0.25 \mathrm{~mm}$, phase thickness $0.25 \mu \mathrm{m}$, carrier gas-helium. Operating modes: injector temperature $270{ }^{\circ} \mathrm{C}$; column temperature programming: $5 \mathrm{~min}$ isotherm at $30{ }^{\circ} \mathrm{C}$, heating at a rate of $10{ }^{\circ} \mathrm{C} / \mathrm{min}$ to $300{ }^{\circ} \mathrm{C}$, then isotherm at $300{ }^{\circ} \mathrm{C}$; energy of ionizing electrons $70 \mathrm{eV}$; source temperature $230{ }^{\circ} \mathrm{C}$, scanning in the range of 20-800 Da at a speed of $1 \mathrm{~s} /$ decade of masses, resolution 1000 .

For 0 products identification, its oxidation reference MS of the NIST 11,17 databases [74] and MS published in the scientific articles were used.

\section{Conclusions}

The distribution-group method of describing the composition of $n$-oxygenation products of 0 , where $n=1-5$ is the number of oxygen atoms included in 0 , introduced as a characteristic of the oxidation depth of $\mathbf{0}$, has shown its effectiveness in searching for conditions and factors contributing to deeper oxidation of $\mathbf{0 .}$

The catalytic system of $50 \% \mathrm{H}_{2} \mathrm{O}_{2} / \mathrm{Cu}_{2} \mathrm{Cl}_{4} \cdot 2 \mathrm{DMG} / \mathrm{CH}_{3} \mathrm{CN}$ was able to deeply oxidize 0 , but positionally $\left(3^{\circ}: 2^{\circ}\right)$ not selectively, with the predominant formation of alcohol, rather than ketone groups. 
At $\mathrm{T}=50{ }^{\circ} \mathrm{C}$ and a fast $(\sim 3 \mathrm{~s})$ method of introducing an oxidizer solution into the reaction mixture, the conversion of $\mathbf{0}$ is determined by the structure of the water-acetonitrile solution, which is formed when different amounts of an aqueous solution of the oxidizer are added.

At $\mathrm{T}=50^{\circ} \mathrm{C}$ and a slow (for $60 \mathrm{~min}$ ) drip method of introducing the oxidizer solution into the reaction mixture at full conversion, 0 is oxidized to a total amount of $72 \%$ of tri-, tetra- and penta-oxygenated products nO-Ad, $n=3-5$, of which $10 \%$ fall on the tertiary triol 1,3,5- $\mathrm{Ad}(\mathrm{OH})_{3}$.

A general pattern is found in the fragmentation of molecular ions of tertiary $\operatorname{Ad}(\mathrm{OH})_{n}{ }^{+\bullet}$, where $n=0-4$, which, as an example, can be useful for interpreting the MS of not only tertiary alcohols but also other $n$-oxygenation products of $\mathbf{0}$.

Author Contributions: Conceptualization, I.Y.S.; methodology, A.L.M., D.N.R. and I.Y.S.; software, I.Y.S. and E.A.B.; validation, I.Y.S., R.S.B. and E.A.B.; formal analysis, D.N.R., A.I.N., R.S.B. and I.Y.S.; investigation, D.N.R., A.I.N., R.S.B. and I.Y.S.; resources, A.L.M.; data curation, I.Y.S.; writing-original draft preparation, I.Y.S.; writing-review and editing, I.Y.S., A.I.N, R.S.B. and E.A.B.; visualization, I.Y.S.; supervision, A.L.M.; project administration, A.L.M.; funding acquisition, A.L.M. All authors have read and agreed to the published version of the manuscript.

Funding: This research was carried out within the State Program of TIPS RAS.

Conflicts of Interest: The authors declare no conflict of interest.

\section{References}

1. Spasov, A.A.; Khamidova, T.V.; Bugaeva, L.I.; Morozov, I.S. Adamantane Derivatives: Pharmacological and Toxicological Properties (Review). Pharm. Chem. J. 2000, 34, 1-7. [CrossRef]

2. Lamoureux, G.; Artavia, G. Use of the Adamantane Structure in Medicinal Chemistry. Curr. Med. Chem. 2010, 17, 2967-2978. [CrossRef] [PubMed]

3. Klimochkin, Y.N.; Shiryaev, V.A.; Leonova, M.V. Antiviral properties of cage compounds. New prospects. Russ. Chem. Bull. 2015, 64, 1473-1496. [CrossRef]

4. Štimac, A.; Šekutor, M.; Mlinarić-Majerski, K.; Frkanec, L.; Frkanec, R. Adamantane in Drug Delivery Systems and Surface Recognition. Molecules 2017, 22, 297. [CrossRef] [PubMed]

5. Thomaston, J.L.; Polizzi, N.F.; Konstantinidi, A.; Wang, J.; Kolocouris, A.; DeGrado, W.F. Inhibitors of the M2 Proton Channel Engage and Disrupt Transmembrane Networks of Hydrogen-Bonded Waters. J. Am. Chem. Soc. 2018, 140, 15219-15226. [CrossRef]

6. Bagrii, E.I.; Nekhaev, A.I.; Maksimov, A.L. Oxidative Functionalization of Adamantanes (Review). Petrol. Chem. 2017, 57, 183-197. [CrossRef]

7. Shibata, S.; Sugahara, K.; Kamata, M.; Hara, K. Liquid-phase oxidation of alkanes with molecular oxygen catalyzed by high valent iron-based perovskite. Chem. Commun. 2018, 50, 6772-6775. [CrossRef]

8. Zima, A.M.; Lyakin, O.Y.; Bryliakov, K.P.; Talsi, E.P. On the nature of the active intermediates in iron-catalyzed oxidation of cycloalkanes with hydrogen peroxide and peracids. Mol. Catal. 2018, 455, 6-13. [CrossRef]

9. Nesterova, O.V.; Kasyanova, K.V.; Makhankova, V.G.; Kokozay, V.N.; Vassilyeva, O.Y.; Skelton, B.W.; Pombeiro, A.J. Stereospecific $\mathrm{sp}^{3} \mathrm{C}-\mathrm{H}$ oxidation with $m$-CPBA: A Co ${ }^{\mathrm{III}}$ Schiff base complex as pre-catalyst vs. its $\mathrm{Co}^{\mathrm{III}} \mathrm{Cd}^{\mathrm{II}}$ heterometallic derivative. Appl. Catal. A 2018, 560, 171-184. [CrossRef]

10. Kislitsina, K.S.; Shchadneva, N.A.; Khusnutdinov, R.I. Oxidation of Adamantane with $\mathrm{H}_{2} \mathrm{O}_{2}-\mathrm{CF}_{3} \mathrm{COCF}_{3} \cdot 1.5 \mathrm{H}_{2} \mathrm{O}$ in the Presence of VO(acac) 2 . Russ. J. Org. Chem. 2018, 54, 992-995. [CrossRef]

11. Lesieur, M.; Battilocchio, C.; Labes, R.; Jacq, J.; Genicot, C.; Ley, S.V.; Pasau, P. Direct Oxidation of Csp ${ }^{3}$-H bonds using in Situ Generated Trifluoromethylated Dioxirane in Flow. Chem. Eur. J. 2019, 25, 1203-1207. [CrossRef]

12. Wang, L.; Zhang, Y.; Du, R.; Yuan, H.; Wang, Y.; Yao, J.; Li, H. Selective One-Step Aerobic Oxidation of Cyclohexane to $\varepsilon$-Caprolactone Mediated by N-Hydroxyphthalimide (NHPI). ChemCatChem 2019, 11, 2260-2264. [CrossRef]

13. Tabushi, I.; Nakajima, T.; Seto, K. The oxidation of adamantane with an iron salen complex modelling $\omega$-hydroxylase. Tetrahedron Lett. 1980, 21, 2565-2568. [CrossRef]

14. Song, S.J.; Kim, K.S.; Kim, K.H.; Kim, J.B.; Kim, J.H.; Kim, K.S.; Shin, H.; Cho, D.L. Highly Selective Production of 2-Adamantanone by Photocatalytic Oxidation of Adamantane. Chem. Lett. 2008, 37, 1052-1053. [CrossRef]

15. Vasil'eva, V.V.; Nekhaev, A.I.; Shchapin, I.Yu.; Bagrii, E.I. On the selectivity of the biomimetic oxidation of the saturated hydrocarbon 1,3-dimethyladamantane in a Gif-type system containing a $\mathrm{Fe}^{2+}$ salt, picolinic acid, and pyridine. Kinet. Catal. 2006, 47, 610-623. [CrossRef]

16. Shchapin, I.Yu.; Vasil'eva, V.V.; Nekhaev, A.I.; Bagrii, E.I. On a possible radical-cation mechanism of the biomimetic oxidation of the saturated hydrocarbon 1,3-dimethyladamantane in a Gif-type system containing a $\mathrm{Fe}^{2+}$ salt, picolinic acid, and pyridine. Kinet. Catal. 2006, 47, 624-637. [CrossRef] 
17. Geluk, H.W.; Schlatmann, J.L.M.A. Hydride transfer reactions of the adamantyl cation (IV): Synthesis of 1,4- and 2,6-substituted adamantanes by oxidation with sulfuric acid. Recueil Travaux Chim. Pays-Bas 1971, 90, 516-520. [CrossRef]

18. Curci, R.; D'Accolti, L.; Detomaso, A.; Fusco, C.; Takeuchi, K.I.; Ohga, Y.; Eaton, P.E.; Yip, Y.C. Selective oxidation of tertiarysecondary vic-diols to $\alpha$-hydroxy ketones by dioxiranes. Tetrahedron Lett. 1993, 34, 4559-4562. [CrossRef]

19. Labes, R.; Battilocchio, C.; Mateos, C.; Cumming, G.R.; de Frutos, O.; Rincón, J.A.; Binder, K.; Ley, S.V. Chemoselective continuous Ru-catalyzed hydrogen-transfer Oppenauer-type oxidation of secondary alcohols. Org. Process Res. Dev. 2017, 21, 1419-1422. [CrossRef]

20. Chen, T.; Xu, Z.; Zhou, L.; Hua, L.; Zhang, S.; Wang, J. Temperature responsive polymer-supported TEMPO: An efficient and recoverable catalyst for the selective oxidation of alcohols. Tetrahedron Lett. 2019, 60, 419-422. [CrossRef]

21. Zhang, W.; Carpenter, K.L.; Lin, S. Electrochemistry broadens the scope of flavin photocatalysis: Photoelectrocatalytic oxidation of unactivated alcohols. Angew. Chem. Int. Ed. 2020, 132, 417-425. [CrossRef]

22. De Araujo, P.L.B.; Mansoori, G.A.; De Araujo, E.S. Diamondoids: Occurrence in fossil fuels, applications in petroleum exploration and fouling in petroleum production. A review paper. Int. J. Oil Gas Coal Technol. 2012, 5, 316-368. [CrossRef]

23. De Gonzalo, G.; Alcántara, A.R. Multienzymatic Processes Involving Baeyer-Villiger Monooxygenases. Catalysts 2021, 11, 605. [CrossRef]

24. Muraoka, O.; Wang, Y.; Okumura, M.; Nishiura, S.; Tanabe, G.; Momose, T. A Facile Synthesis of 7-Methylenebicyclo-[3.3.1]nonan3-one and its Transformation Leading to the Novel Tricyclic System, Protoadamantane. Synth. Commun. 1996, 26, 1555-1562. [CrossRef]

25. Ho, T.C. The total synthesis of c1'-azacycloalkyl hexahydrocannabinoids; the total synthesis of 3-oxaadamantyl hexahydrocannabinoids; the synthesis of bicyclic 3-adamantyl cannabinoids. Doctoral dissertation, University of Hawaii at Manoa, Honolulu, HI, USA, 2014. Available online: http:/ / hdl.handle.net/10125/101085 (accessed on 18 August 2021).

26. Itoh, H.; Kato, I.; Unoura, K.; Senda, Y. Regioselectivity on Electroreductive Transannular Reaction of 7-Methylenebicyclo[3.3.1] nonan-3-one. Bull. Chem. Soc. Jpn. 2001, 74, 339-345. [CrossRef]

27. White, R.E.; McCarthy, M.B.; Egeberg, K.D.; Sligar, S.G. Regioselectivity in the cytochromes P-450: Control by protein constraints and by chemical reactivities. Arch. Biochem. Biophys. 1984, 228, 493-502. [CrossRef]

28. Mitsukura, K.; Kondo, Y.; Yoshida, T.; Nagasawa, T. Regioselective hydroxylation of adamantane by Streptomyces griseoplanus cells. Appl. Microbiol. Biotechnol. 2006, 71, 502-504. [CrossRef]

29. Mitsukura, K.; Sakamoto, H.; Kubo, H.; Yoshida, T.; Nagasawa, T. Bioconversion of 1-adamantanol to 1,3-adamantanediol using Streptomyces sp. SA8 oxidation system. J. Biosci. Bioeng. 2010, 109, 550-553. [CrossRef]

30. Mitsukura, K.; Yamanaka, N.; Yoshida, T.; Nagasawa, T. Regioselective synthesis of 1,3,5-adamantanetriol from 1,3adamantanediol using Kitasatospora cells. Biotechnol. Lett. 2012, 34, 1741-1744. [CrossRef]

31. Bell, S.G.; Yang, W.; Dale, A.; Zhou, W.; Wong, L.L. Improving the affinity and activity of CYP101D2 for hydrophobic substrates. Appl. Microbiol. Biotechnol. 2013, 97, 3979-3990. [CrossRef]

32. Md Sarkar, R.; Hall, E.A.; Dasgupta, S.; Bell, S.G. The use of directing groups enables the selective and efficient biocatalytic oxidation of unactivated adamantyl C-H bonds. ChemistrySelect 2016, 1, 6700-6707. [CrossRef]

33. Alcántara, C.M.; Alcántara, A.R. Biocatalyzed synthesis of antidiabetic drugs: A review. Biocatal. Biotransform. 2018, 36, 12-46. [CrossRef]

34. Sarkar, M.R. Application of the Monooxygenase Enzymes CYP101B1 and CYP101C1 from Novosphingobium aromaticivorans for Selective and Efficient Functionalisation of Inert CH bonds. Doctoral dissertation, School of Physical Sciences, University of Adelaide, Adelaide, Australia, 2019. Available online: http://hdl.handle.net/2440/119892 (accessed on 18 August 2021).

35. Furuya, T.; Kanno, T.; Yamamoto, H.; Kimoto, N.; Matsuyama, A.; Kino, K. Biocatalytic production of 5-hydroxy-2-adamantanone by P450cam coupled with NADH regeneration. J. Mol. Catal. B Enzym. 2013, 94, 111-118. [CrossRef]

36. Selifonov, S.A. Microbial oxidation of adamantanone by Pseudomonas putida carrying the camphor catabolic plasmid. Biochem. Biophys. Res. Commun. 1992, 186, 1429-1436. [CrossRef]

37. Wei, Z.; Moldowan, J.M.; Peters, K.E.; Wang, Y.; Xiang, W. The abundance and distribution of diamondoids in biodegraded oils from the San Joaquin Valley: Implications for biodegradation of diamondoids in petroleum reservoirs. Org. Geochem. 2007, 38, 1910-1926. [CrossRef]

38. Ohshita, J.; Hino, K.; Inata, K.; Kunai, A.; Maehara, T. Palladium-catalyzed silation of adamantanedi- and triol, leading to adamantane-siloxane alternating polymers with high heat resistance. Polymer 2007, 48, 4301-4304. [CrossRef]

39. Sayed, S.M.; Lin, B.P.; Yang, H. Generation of liquid crystallinity from a $T_{\mathrm{d}}$-symmetry central unit. Soft Matter 2016, $12,6148-6156$. [CrossRef]

40. Stetter, H.; Krause, M. Zur kenntnis der 1.3.5.7-tetrasubstituierten adamantane. Tetrahedron Lett. 1967, 8, 1841-1843. [CrossRef]

41. Stetter, H.; Krause, M. Über Verbindungen mit Urotropin-Struktur, XLII. Über 1.3.5.7-tetrasubstituierte Adamantane. Justus Liebigs Ann. Chem. 1968, 717, 60-63. [CrossRef]

42. Moiseev, I.K.; Belyaev, P.G.; Tartakovskii, V.A. Fragmentation reaction of 1,3,5,7-tetrabromoadamantane. Russ. Chem. Bull. 1973, 22, 245. [CrossRef]

43. Sollott, G.P.; Gilbert, E.E. A facile route to 1,3,5,7-tetraaminoadamantane. Synthesis of 1,3,5,7-tetranitroadamantane. J. Org. Chem. 1980, 45, 5405-5408. [CrossRef] 
44. Menger, F.M.; Migulin, V.A. Synthesis and Properties of Multiarmed Geminis. J. Org. Chem. 1999, 64, 8916-8921. [CrossRef] [PubMed]

45. Huang, C.-F.; Lee, H.-F.; Kuo, S.-W.; Xu, H.; Chang, F.-C. Star polymers via atom transfer radical polymerization from adamantanebased cores. Polymer 2004, 45, 2261-2269. [CrossRef]

46. Grillaud, M.; Bianco, A. Multifunctional adamantane derivatives as new scaffolds for the multipresentation of bioactive peptides. J. Pept. Sci. 2015, 21, 330-345. [CrossRef]

47. Fu, S.-Q.; Guo, J.-W.; Zhu, D.-Y.; Yang, Z.; Yang, C.-F.; Xian, J.-X. Li, X. Novel halogen-free flame retardants based on adamantane for polycarbonate. RSC Adv. 2015, 5, 67054-67065. [CrossRef]

48. Wang, X.; Dong, Y.; Ezell, E.L.; Garrison, J.C.; Wood, J.K.; Hagen, J.P.; Vennerstrom, J.L. Semipinacol and protoadamantaneadamantane rearrangements of 5,6-dibromoadamantan-2-one and -2-ol. Tetrahedron 2017, 73, 2972-2976. [CrossRef]

49. Schwenger, A.; Birchall, N.; Richert, C. Solution-Phase Synthesis of Branched Oligonucleotides with up to 32 Nucleotides and the Reversible Formation of Materials. Eur. J. Org. Chem. 2017, 39, 5852-5864. [CrossRef]

50. Nasrallah, H.; Hierso, J.C. Porous Materials Based on 3-Dimensional Td-Directing Functionalized Adamantane Scaffolds and Applied as Recyclable Catalysts. Chem. Mater. 2018, 31, 619-642. [CrossRef]

51. Klapoetke, T.M.; Krumm, B.; Widera, A. Synthesis and Properties of Tetranitro-Substituted Adamantane Derivatives. ChemPlusChem 2018, 83, 61-69. [CrossRef]

52. Fu, S.; Zhu, J.; Chen, S. Tunable Shape Memory Polyurethane Networks Cross-Linked by 1,3,5,7-Tetrahydroxyadamantane. Macromol. Res. 2018, 26, 1035-1041. [CrossRef]

53. Li, M.; Guo, J.-W.; Wen, W.-Q.; Chen, J.K. Biodegradable Redox-Sensitive Star Polymer Nanomicelles for Enhancing Doxorubicin Delivery. Nanomaterials 2019, 9, 547. [CrossRef]

54. Tominaga, M.; Katagiri, K.; Azumaya, I. Hydrogen-bonded networks formed from tri- and tetra-substituted adamantanes bearing dimethoxyphenol moieties and their 1,3,5-trinitrobenzene complexes via charge-transfer interactions. CrystEngComm. 2010, 12, 1164-1170. [CrossRef]

55. Alexandre, P.E.; Schwenger, A.; Frey, W.; Richert, C. High-Loading Crystals of Tetraaryladamantanes and the Uptake and Release of Aromatic Hydrocarbons from the Gas Phase. Chem. Eur. J. 2017, 23, 9018-9021. [CrossRef]

56. Reddy, D.S.; Craig, D.C.; Desiraju, G.R. Topological Equivalences between Organic and Inorganic Crystal Structures: 1,3,5,7Tetrahydroxyadamantane and Caesium Chloride. J. Chem. Soc. Chem. Commun. 1995, 3, 339-340. [CrossRef]

57. Mello, R.; Cassidei, L.; Fiorentino, M.; Fusco, C.; Curci, R. Oxidations by methyl(trifluoromethyl)dioxirane. 3. Selective polyoxyfunctionalization of adamantane. Tetrahedron Lett. 1990, 31, 3067-3070. [CrossRef]

58. D'Accolti, L.; Annese, C.; Fusco, C. Continued Progress towards Efficient Functionalization of Natural and Non-natural Targets under Mild Conditions: Oxygenation by C-H Bond Activation with Dioxirane. Chem. Eur. J. 2019, 25, 12003-12017. [CrossRef] [PubMed]

59. Hitomi, Y.; Arakawa, K.; Kodera, M. Electronic Tuning of Iron-Oxo-Mediated C-H Activation: Effect of Electron-Donating Ligand on Selectivity. Chem. Eur. J. 2013, 19, 14697-14701. [CrossRef] [PubMed]

60. Ishii, Y.; Kato, S.; Iwahama, T.; Sakaguchi, S. Hydroxylation of polycyclic alkanes with molecular oxygen catalyzed by N-hydroxyphthalimide (NHPI) combined with transition metal salts. Tetrahedron Lett. 1996, 37, 4993-4996. [CrossRef]

61. Ivleva, E.A.; Platonov, I.A.; Klimochkin, Y.N. Improved approach towards synthesis of adamantane-1,3,5-triol. Russ. J. Gen. Chem. 2015, 85, 1830-1833. [CrossRef]

62. Fu, C.A.; Guo, J.; Liu, S.; Cui, Y.; Yang, C.; Peng, J.; Cui, Y. A novel synthesis of adamantane polyhydric alcohols by direct oxidation of adamantine. CIESC J. 2011, 62, 3428. [CrossRef]

63. Zhu, H.; Guo, J.; Yang, C.; Liu, S.; Cui, Y.; Zhong, X. Synthesis of Adamantane-Based Trimeric Cationic Surfactants. Synth. Commun. 2013, 43, 1161-1167. [CrossRef]

64. Nesterova, O.V.; Nesterov, D.S.; Krogul-Sobczak, A.; da Silva, M.F.C.G.; Pombeiro, A.J. Synthesis, crystal structures and catalytic activity of $\mathrm{Cu}$ (II) and $\mathrm{Mn}$ (III) Schiff base complexes: Influence of additives on the oxidation catalysis of cyclohexane and 1-phenylehanol. J. Mol. Cat. A Chem. 2017, 426, 506-515. [CrossRef]

65. Shul'pin, G.B.; Shul'pina, L.S. Oxidation of Organic Compounds with Peroxides Catalyzed by Polynuclear Metal Compounds. Catalysts 2021, 11, 186. [CrossRef]

66. Stavropoulos, P.; Çelenligil-Çetin, R.; Tapper, A.E. The Gif paradox. Acc. Chem. Res. 2001, 34, 745-752. [CrossRef] [PubMed]

67. Butov, G.M.; Mokhov, V.M.; Ledenev, S.M.; Terent'ev, A.O. Method of producing 1-adamantylhydroperoxide. Patent RU 2471780 C1, 25 November 2011. (In Russian).

68. Terent'ev, A.O.; Platonov, M.M.; Ogibin, Y.N.; Nikishin, G.I. Convenient synthesis of geminal bishydroperoxides by the reaction of ketones with hydrogen peroxide. Synth. Commun. 2007, 37, 1281-1287. [CrossRef]

69. Sharma, C.; Joy, J.; Nethaji, M.; Jemmis, E.D.; Awasthi, S.K. Synthetic, Crystallographic, and Computational Studies of Extensively Hydrogen Bonded Bilayers in Thermally Stable Adamantane Hydroperoxides. Asian J. Org. Chem. 2016, 5, 1398-1405. [CrossRef]

70. Ramazanov, D.N.; Kluev, M.V. Oxidation of cyclohexane to adipinic acid by hydrogen peroxide in the presence of copper complexes. Russ. J. Chem. And Chem. Tech. 2009, 52, 44-46. (In Russian).

71. Svedung, D.H. The crystal structure of copper dimethylglyoxime dichloride. Acta Chem. Scand. 1969, 23, 2865-2878. [CrossRef]

72. Gawlig, C.; Schindler, S.; Becker, S. One-Pot Conversion of Cyclohexane to Adipic Acid Using a $\mu 4$-Oxido-Copper Cluster as Catalyst Together with Hydrogen Peroxide. Eur. J. Inorg. Chem. 2020, 2020, 248-252. [CrossRef] 
73. Ribeiro, A.P.C.; Spada, E.; Bertani, R.; Martins, L.M.D.R.S. Adipic Acid Route: Oxidation of Cyclohexene vs. Cyclohexane. Catalysts 2020, 10, 1443. [CrossRef]

74. Stein, S.E. NIST/EPA/NIH Mass Spectral Database (NIST 11,17) and NIST Mass Spectral Search Program, version 2.0g; National Institute of Standards and Technology: Gaithersburg, MD, USA, 2011.

75. Takamuku, T.; Tabata, M.; Yamaguchi, A.; Nishimoto, J.; Kumamoto, M.; Wakita, H.; Yamaguchi, T. Liquid Structure of Acetonitrile-Water Mixtures by X-ray Diffraction and Infrared Spectroscopy. J. Phys. Chem. B 1998, 102, 8880-8888. [CrossRef]

76. Monakhova, Y.B.; Mushtakova, S.P.; Kolesnikova, S.S.; Gribov, L.A. Spectral-chemometric and quantum-chemical study of the water-acetonitrile system. J. Anal. Chem. 2011, 66, 53-59. [CrossRef]

77. Monakhova, Y.B.; Mushtakova, S.P. Methanol and acetonitrile associates in aqueous and chloroform solutions according to ${ }^{1} \mathrm{H}$ NMR spectroscopic data. Russ. J. Phys. Chem. A 2014, 88, 798-802. [CrossRef]

78. Stepakova, L.V.; Skripkin, M.Yu.; Korneeva, V.V.; Grigoriev, Ya.M.; Burkov, K.A. Organic solvent effect on the solution-solid phase equilibria in the systems $\mathrm{CuCl}_{2}-\mathrm{L}-\mathrm{H}_{2} \mathrm{O}$ ( $\mathrm{L}=\mathrm{DMSO}, \mathrm{DMF}$, acetonitrile) at $25^{\circ} \mathrm{C}$. Russ. J. Gen. Chem. 2009, 79, 1053-1056. [CrossRef]

79. Bouwman, J.; Horst, S.; Oomens, J. Spectroscopic Characterization of the Product Ions Formed by Electron Ionization of Adamantane. Chem. Phys. Chem. 2018, 19, 3211-3218. [CrossRef] [PubMed]

80. Candian, A.; Bouwman, J.; Hemberger, P.; Bodi, A.; Tielens, A.G. Dissociative ionisation of adamantane: A combined theoretical and experimental study. Phys. Chem. Chem. Phys. 2018, 20, 5399-5406. [CrossRef]

81. Solcà, N.; Dopfer, O. Protonated Benzene: IR Spectrum and Structure of $\mathrm{C}_{6} \mathrm{H}_{7}{ }^{+}$. Angew. Chem. Int. Ed. 2002, 41, 3628-3631. [CrossRef]

82. Rode, M.F.; Sobolewski, A.L.; Dedonder, C.; Jouvet, C.; Dopfer, O. Computational Study on the Photophysics of Protonated Benzene. J. Phys. Chem. A 2009, 113, 5865-5873. [CrossRef] [PubMed]

83. Garkusha, I.; Fulara, J.; Nagy, A.; Maier, J.P. Electronic Transitions of Protonated Benzene and Fulvene, and of $\mathrm{C}_{6} \mathrm{H}_{7}$ Isomers in Neon Matrices. J. Am. Chem. Soc. 2010, 132, 14979-14985. [CrossRef]

84. Chen, H.-F.; Wu, Y.-J. Structure, stability, and vibrational fundamentals of low-lying isomers of $\mathrm{C}_{6} \mathrm{H}_{7}{ }^{+}$. Comput. Theor. Chem. 2013, 1006, 100-104. [CrossRef] 